Çanakkale Onsekiz Mart Üniversitesi Fen Bilimleri

Enstitüsü Dergisi, 2016:2, 1, 36-57

Çanakkale Onsekiz Mart University, Journal of Graduate

School of Natural and Applied Sciences, 2016:2, 1, 36-57

\title{
Depreme Maruz Kalmış Yığma ve Kırsal Yapı Davranışlarının İncelenerek Yığma Yapı Yapımında Dikkat Edilmesi Gereken Kuralların Derlenmesi
}

\author{
Varol Koç ${ }^{1}$ \\ ${ }^{1}$ Ondokuz Mayıs Üniversitesi Mühendislik Fakültesi İnşaat Mühendisliği Bölümü Kurupelit / \\ SAMSUN
}

Özet

$\mathrm{Bu}$ çalışmada, yığma yapılarda depremler sonrası oluşmuş hasar şekilleri, geçmişte yapılan çalışmalar da incelenerek ortaya konulmaya, yığma yapı davranışının özellikle deprem yükleri altında irdelenmesine ve bu hususta bazı öneriler getirilmeye çalışılmıştır. Literatürde dağınık olarak bulunan önerilerin başlıcaları birleştirilerek, genelde yığma ve özelde kırsal yapı yapımında dikkat edilmesi gereken kuralların formüle edilmesi amaçlanmış, depremler sonrası hasarların ağırlıklı olarak, bu kurallardan hangisinin ihlalinden dolayı oluştuğu gösterilmeye çalışılmıştır.

Anahtar Sözcükler: deprem, kırsal yapı, yapısal davranış yığma yapı

\section{Examined to the Behavior of Earthquake Exposed Masonry And Rural Buildings With Construction Rules to be Considered in Masonry Structures}

\begin{abstract}
In this study, any damage after earthquakes in masonry forms, past studies have tried to put forward in examining. Particularly of masonry structures under seismic loads to be examined behavioral and has tried to bring some recommendations in this regard. The main proposal of combining scattered and partially identified in the literature generally should be considered in making the rules on rural buildings and private stockpiling has tried to be formulated. Mainly the damage after the earthquake, it has tried to show that which arises from the violation of these rules.
\end{abstract}

Keywords: earthquake, masonry structures, rural construction, structural behavior

\section{Giriş}

Yı̆̆ma yapılar ileriki bölümlerde de açıklanacağı üzere bazı açılardan üstün olmalarına karşın, çok ağır olmaları ve deprem gibi dinamik ve yatay yüklere dayanımlarının az olması nedeniyle, genellikle depreme dayanıklı yapı olarak nitelendirilmezler. (Bayülke, 1992). Ancak özellikle ekonomik koşullardan dolayı, Türkiye'de genelde yığma, özelde ise kırsal *Sorumlu Yazar (Corresponding Author): Varol Koç (e-posta: kvarol@omu.edu.tr) 
yapı yapımı azalarak da olsa devam etmektedir. Daha da önemlisi mevcut yığma- kırsal yap1 stokunun iyileştirilmesi gereği nedeniyle, bu yapıların elden geldiğince depreme dayanıklı yapılması ya da güçlendirilmesi, bunun için de, depremlerdeki davranışlarının bilinmesi ve bu bilgi ışığında deprem dayanımlarının arttırılması gerekmektedir. 1984 yılında yapılan bina sayımına göre, Türkiye' de iskelet (karkas) olarak inşa edilen binaların toplam bina içindeki oran $1 \% 30$, yığma binaların ise $\% 70^{\prime}$ iken, 2000 yılında yapılan bina sayımına göre binaların \%48'i iskelet, \%51'i yığmadır (TCBDİE, 2001). Günümüzde, oranlardaki bu değişimi de dikkate alarak, yığma yapı oranının çok daha düştügü rahatlıkla söylenebilir. Ancak halen kullanımda olan hem kamu (Örneğin 2000 yılı itibariyle Türkiye genelinde 2472 civarında tuğla yığma okul binası vardır (TCBDİE, 2001).) hem de özel konut tipinde yapılmış çok sayıda yığma yapının varlığı, tarihi yığma yapılar ve özellikle kırsal yapılar bu konunun önemini göstermektedir.

Kırsal yapı tanımı, genellikle duvarları moloz taştan yapılmış, çamur harçlı ve düz toprak damlı yapılar için kullanılmaktadır. Bu yapıların duvar- taş işçiliği ve duvar- dam bağlantıları yeteri kadar yapılamamaktadır. Böyle bir damın ağırlığı 0.75-1.00 ton $/ \mathrm{m}^{2}$ olmaktadır. $12 \mathrm{~cm}$ kalınlığında betonarme bir tabliyenin ağırlığı ise $0.300 \mathrm{ton} / \mathrm{m}^{2}$ 'dir (Bayülke, 2011). Türkiye nüfusunun yaklaşık \%30'u köylerde ikamet etmekte, köylerde yaşayan halkın büyük bölümü tarımla geçimini sağlamakta ve kırsal yapılar adı verilebilecek 1-2 katlı ahşap karkaslı kerpiç yapılar, ahşap destekli yığma- kerpiç yapılar ve betonarme lento destekli tuğla ve briket yığma yapılarda oturmaktadır (Alkaya, 2005).

Ayrıca, bazı yığma yapılar yüzlerce yıl önce yapıldıkları için anıtsal nitelik kazanmışlardır. Deprem davranış ve dayanımlarının bilinmesi özellikle kalıcılıklarının sürdürülebilmesi için gereklidir. On dokuzuncu ve Yirminci yüzyılda yapılmış ve bugün anıtsal ve tarihi değeri olan pek çok yığma yapı vardır. $\mathrm{Bu}$ yapıların en önemli sıkıntısı deprem davranış ve dayanımlarının bilinmemesi ve belirlenmesi için de geçerli ve kabul edilmiş yöntemlerin olmamasıdır. Yığma yapılar bugün yapı tasarımında çok istenen "sünek" davranıştan yoksundur. Bir yandan tarihsel yapı olmalarından dolayı depremden korunmaları gerekirken, diğer yandan bunun gereğini yerine getirmek ya olanaksızdır ya da süneklik sağlamak yapının özgün niteliğini bozmaktadır. Bazı ülkelerde bu yapıların çok önemli ve tarihsel değeri olanları "taban yalıtımı" yöntemi ile deprem titreşimlerinden korunmaktadır. Ancak bu yönteminde bedeli oldukça yüksektir. Tüm bunlarla birlikte, anıtsal nitelikte olsun ya da olmasın yığma duvarlı yapıların deprem davranış ve dayanımları kullanıcılarının can güvenliği ve gerekiyorsa güçlendirilmeleri için bilinmelidir (Bayülke, 2011).

\subsection{Yığma yapı yapımındaki düşüş ve yapısal sorunlar}

Türkiye'de 1960'lı y1llarda yerel olanaklar ve üstün işçilik gerektirmediği için okul, sağlık ocağı ve kamu personeli lojmanı gibi yapılar harman tuğlasıyla yığma olarak yapılmıştır. Bununla birlikte, betonarme plak kat döşemeli tuğla yığma duvarlı evler 1960 -1970 'li yıllardan sonra giderek yapılmamaya başlanmıştır. 1970 'li yıllardan sonra çimentonun daha bol üretiminin de katkısı ile betonarme yapılar yaygınlaşmıştır. Harman tuğlasına göre daha hafif delikli fabrika tuğlaları çok uzaklara kadar ekonomik olarak taşınmaya başlayınca betonarme çerçeveli ve dolgu tuğla duvarlı yapılar tuğla yığma duvarlı yapıların yerine geçmiştir. Bu değişimin bir başka nedeni de, tuğlaların basınç dayanımlarının düşük olması ve \% 35'den az delik oranlı tuğlaların daha ağır olmalarından dolayı hem inşaat alanına taşınmalarının hem de duvara konulmalarının daha çok emek ve bedel gerektirmesidir. Genel olarak tuğla yığmanın istediği nitelikli duvar örgü işçiliğinin bedeli de yükselmiştir. Delik oranı \% 35'den az olan tuğlaların pişirilmeden önce çok iyi, genelde enerji harcanarak 
kurutulma gereksinimi de, bedellerinin yükselmesine ve üretimden kaçınılmasına neden olmuştur. Ancak çok sayıda tuğla yığma yapı hâlihazırda yapılmış durumdadır (Bayülke, 2011). Ayrıca tüm bu nedenlerden dolayı yığma yapı yapımı günümüzde oldukça düşse de, halen özellikle kırsal yapılarda çoklukla kullanılan tek yöntem olduğu da bir gerçektir.

Genelde yığma, özelde kırsal yapılar genellikle mühendislik eğitimi almamış ev sakinleri tarafından inşa edilmektedir (Gölalmış, Türer, 2005). Az gelişmiş veya gelişmekte olan ülkelerde, kırsal kesimde ve şehirlerin gecekondu bölgelerinde konutlar, kullanıcıları tarafindan, taş, kerpiç, briket veya pişmiş toprak tuğlalardan yı̆̆ma yapı şeklinde inşa edilmektedir. Bu yapılar deprem gibi yatay yükler altında zayıf dayanım göstermektedir. Son depremlerde İran ve Türkiye'de kırsal kesimde hayat kaybı büyük olmuştur (Korkmaz vd, 2005). Depreme dayanıklı yapı yapabilmek için araştırma çabaları, çok büyük ölçüde betonarme ve çelik yapılar üzerinedir. Batıdaki ülkeler için bu anlamlıdır, çünkü söz konusu ülkelerde olağan yapı tipi betonarme ve çeliktir. Oysa Türkiye'de olduğu kadar, Orta doğu ve doğuda yer alan ülkelerde tuğla, kerpiç ve taş yığma duvarlar geleneksel yapı tipini oluşturmaktadır. Buradan hareketle, yığma binaların deprem davranışını anlamak ve bu tip yapıları depreme güvenli duruma getirmek son derece önem kazanmaktadır. Betonarme ve çelik yapıların deprem davranışını bilen mühendis, yığma binaların deprem davranışı üzerinde yorum yapamayabilmektedir (Kanıt vd, 2005). Zira yığma yapıların deprem davranışı, yatay ve düşey yük taşıma düzenleri, duvarlarında oluşan yatay ve düşey gerilmelerin hesabı ve daha birçok konu inşaat mühendisliği eğitiminde yoktur. Bu eğitimin verilmediği ya da bu eğitimi almamış pek çok mühendis bu yığma yapıların deprem dayanımını değerlendirmekte ve kaderlerini belirlemektedir. Anıtsal değeri olmayan yığma yapıları daha dayanıklı betonarme yapılarla yenilemek kolay ve daha güvenli görünen bir çözüm olabilir. Ancak anıtsal değeri olanlar yapılar için davranışı ve güçlendirme yöntemlerini bilmek zorunluluğu inşaat mühendisinin bu yapıları daha iyi tanımasını ve çalışmasını gerektirmektedir (Bayülke, 2011). Bununla beraber, depremler nedeni ile meydana gelen can ve mal kayıpları yalnız kentsel alanları değil, kırsal alanları da olumsuz etkilemektedir. Kırsal kesimlerde konutların büyük çoğunluğu yığma yapılardan oluşmaktadır. Türkiye kırsalında bulunan yığma yapılar, çoğunlukla tuğla, çamur, briket ve taş, vb. malzemelerin harç ile bir araya getirilmesi ile yapıldıklarından, taşıyıcı sistem açısından, sürekli bir ortam oluşturmazlar (Tokgöz, Can, 2011).

Nispeten değinildiği üzere, yığma yapılar daha çok kırsal alanlarda ve 80’lerden sonra yaşanan şehirleşme ve metropolleşme sonucu şehir olma hüviyetini kazanmış ve büyük şehirlere gerçekleşen göç sonucu büyüyen merkezi yerleşim yerlerinde görülmektedir. $\mathrm{Bu}$ yapıların çoğunun mühendislik hizmeti almamış olması ve hem bu nedenle hem de standartların bu konudaki yetersizliğinden dolayı bir nevi, inşalarının deprem standartlarına dâhil edilmemiş gibi olması, bu yapıları deprem etkilerine karşı korunmasız ve içinde barınan insanları da muhtemel can ve mal kaybıyla yüz yüze bırakmaktadır. Zira TSE'nin yapı ve inşaatla ilgili olarak düzenlediği standartlar arasında TS-647 gibi ahşap ve TS-2515 gibi kerpiç yığma yapılarla ilgili kodlara rastlamak mümkünken, tuğla ve briket yığma binalarla ilgili standartlara rastlanamamaktadır. Afet deprem yönetmeliğinde bulunan yı̆̆ma yap1 bölümünün yeterliliği ve uygulamasındaki eksikler ise halen tartışma konusudur. Bu durum, Türkiye'nin büyük bir kısmında rastlanan bu tür yapılar için büyük bir boşluk yaratmaktadır (Şimşek, 2005).

Büyük çoğunluğu mühendis eli değmeden inşa edilen yığma yapıların, betonarme ve çelik taşıyıcı sistemli yapıların yetkin mühendislerin gözetiminde inşa edilmesini sağlayacak yasal düzenlemelerden pozitif yönde etkilenmesini beklemek de gerçekçi olmayacaktır. Benzer 
şekilde, mühendisi ve müteahhidi olmayan çoğu yığma yapılar için yap1 denetim yasalarının işlerliğini sağlamak da pek mümkün görülmemektedir. DASK tarafından oluşturulmuş yapı sigorta sisteminde, yükümlünün deprem sonrası, ikamet ettiği yapının hasarlarını karşılamak üzere oluşturulan sigortanın poliçe yükümlüsü ev ya da daire sahipleri olduğu için, ekonomik göstergelerde genelde alt sıralarda yer alan yığma yapı kat sahipleri DASK sigortalarını bir seçenek olarak algılamayabilmektedir. Diğer taraftan bu tür binaların yükssek risk faktörleri, düşük poliçeli kamusal sigortalama metotlarının da verimliliğini düşürebilir durumdadır (Şimşek, 2005).

Yığma yapıların tercih edilmesinin nedeni, yerel malzemelerden kolaylıkla yapılabilir ve ekonomik olmalarıdır. Bu tür yapılar, genellikle, yeterli mühendislik bilgisi olmadan standartlara bakılmaksızın gelişigüzel olarak inşa edilmektedirler. Belirtildiği üzere, yığma yapılar, tuğla ve harç gibi gevrek malzemelerden oluştukları için, süneklikleri düşüktür. Geleneksel yapıların ve özellikle kırsal kesimlerde konut ve hayvan barınağı olarak siklıkla kullanılan bu yapı türünün hasar şekillerinin incelenmesi ve bu doğrultuda önlemler alınması gerekmektedir (Çırak, 2011). Bu nedenlerle bu çalışmada, yığma yapılarda depremler sonrası oluşmuş hasar şekilleri, geçmişte yapılan çalışmalar da incelenerek ortaya konulmaya, yığma yapı davranışının özellikle deprem yükleri altında irdelenmesine ve bu hususta bazı öneriler getirilmeye çalışılmıştır.

\subsection{Düzgün yığma yapıların bazı avantajları}

Deprem etkisi altında yığma yapıların çerçeveli yapılara göre bazı belirgin avantajları vardır. Bunların başlıcaları şöyle sıralanabilir (ODTÜ, 1995):

1- Kutu şeklindeki taşıyıcı sistemleri basit ve süreklidir.

2- Düşey yükleri taşıyan duvar elemanları yatay yükler altında perde duvarı olarak görev yaparlar.

3- Taşıyıcı sistemde düğüm noktaları olmadığı için iç kuvvetler belirli bölgelerde aşırı değerlere ulaşmazlar ve oldukça düzgün bir dağılım gösterirler.

4- Yığma sistemin kuruluşu ve yapımı basit olduğundan kalifiye işçilik gerektirmez, sistem işçilik hataları tolere edebilir.

Ayrıca, Anadolu'da geleneksel olarak zemin düzeltildikten ve $15-20 \mathrm{~cm}$ kalınlığında kum serildikten sonra temel yapımına geçilir. Temel altına serilen kumun zemin suyunu yapıya iletmemesinin yanında depremde yer sarsıntılarını sönümlemesi açısından da yararı vardır (Arun, 2005).

Tüm bunlara ek olarak, elbette yığma yapılar düzgün, deprem bölgesine göre uygun kat sayısında ve mühendislik kurallarına riayet edilerek yapılırsa, avantajlarından bahsetmek mümkündür. Örneğin deprem bölgelerinde dolu tuğla ve çimento harc1 ile özenli olarak örülen bir- iki katlı tuğla yığma binalarda, her iki yönde duvar alanı plan alanının yüzde onundan fazla ise, bu binaların yeterli deprem güvenliğine sahip olduğuna kanaat getirmek mümkündür (ODTÜ, 1995).

\subsection{Bu çalışma kapsamında incelenen depremler}

1970 Gediz Depremi, 28 Mart 1970’te 7,2 büyüklüğünde olmuş, 1086 kişinin ölümü, 9473 binanın ağır hasarı ya da yıkımı, 9800 binanın orta, 7889 binanın da hafif hasarıyla sonuçlanmıştır. Ağır hasarlı yapıların çok büyük bir bölümü yığma yapılardır. Gediz'de 1918 
Koca Yangınında evlerin tamamına yakını yanmış ve kasabanın halkı o günün koşullarında buldukları malzemeleri kullanarak, mühendislik hizmeti olmadan, yeni evler yapmıştır. Çoğu yapının temelinde yuvarlak dere taşı ve harç olarak çamur kullanılmıştır.

1975 Lice Depremi, 6 Eylül 1975 tarihinde Diyarbakır'ın Lice ilçesi ve köylerinde oluşan 23 saniye süren 6,6 büyüklüğünde bir depremdir. 2385 kişinin ölümüne, 8149 binanın ağır hasarı ya da yıkılmasına, 4550 binanın orta, 7283 binanın da hafif hasarına ve bazıları maddi hasarlara sebep olan 3-4 ay süresince artçı sarsıntılara neden olmuştur.

1992 Erzincan Depremi, 13 Mart 1992 tarihinde 6,8 büyüklüğünde olmuş, 653 kişinin ölümü, 8057 binanın ağır hasarı ya da yıkımı ile sonuçlanmıştır. Erzincan, bu depremle beraber tarihindeki altıncı büyük depremi yaşamıştır. 1992 Erzincan depreminde, çok katlı olup sarsıntıyı çok az hasarla geçirmiş betonarme yapıların yanında, bir veya iki katlı basit pek çok betonarme karkas veya yığma yapının da depremi hasarsız atlattı̆̆ gözlenmiştir. Önemli hiçbir hasarın görülmediği, bölme duvarları harman tuğlası ile yapılmış betonarme iki katlı binalar da vardır. Ayrıca yanında göçen ve kendisine çarpan çok katlı betonarme yapının ve depremin dinamik etkilerine karşın bölgesel çatı hasarlarından başka hiçbir önemli hasar göstermemiş olan tek katlı yığma tuğla binalar bile mevcuttur (İTÜ, 1992).

1995 Dinar Depremi, 1 Ekim 1995 tarihinde Afyonkarahisar'ın Dinar ilçesinde 6,1 büyüklügüunde olmuş, 90 kişinin ölümü, 14.156 binanın hasarı ile sonuçlanmıştır. $\mathrm{Bu}$ bölgenin 2000 yıllık tarihinde yüksek şiddetli en az 18 deprem meydana gelmiştir. Cumhuriyet döneminde ise Dinar'da 1925 ve 1971 yıllarında etkili depremler yaşanmıştır. 1995 Dinar depreminde de ahşap karkaslı kerpiç dolgulu evler depremi genelde az hasarlı veya hasarsız olarak atlatmışlardır (ODTÜ, 1995). Gerek 1992 Erzincan depreminde, gerekse 1995 Dinar depreminde yığma yapılardaki hasar miktarı diğer yapılardaki hasara oranla düşük düzeylerde olmuştur.

2002 Sultandağı Depremi, 03.02.2002 tarihinde Sultandağı fayı üzerinde 6 büyüklüğünde meydana gelmiş, 43 kişinin ölümüne ve çok sayıda yaralıya neden olmuş, özellikle kırsal yapılar depreme dayanamamıştır. Depremin bu kadar etkili olmasının bir nedeni de, 5- 6 büyüklüğünde artçı sarsıntıların sürmesidir. Depremden birkaç saat sonra halkla yapılan görüşmelerde ilk sarsıntıda yıkılmayan evlerin 2. Sarsıntıda yıkıldığı öğrenilmiştir. Ayrıca zeminin kurumuş bataklık ve alüvyon zemin olması deprem etkisini büyüten önemli bir faktördür. Hasar ve kayıpların yoğun olduğu beldeler tamamen kırsal yapılardan oluşturan 12 katlı ahşap karkaslı kerpiç yapılar, ahşap destekli yığma kerpiç yapılar ve tuğla yığma yapılardan oluşmaktadır (Alkaya, 2005).

2003 Bingöl Depremi, 01.05.2003 tarihinde 6,4 büyüklüğünde meydana gelmiş, yüksek yapısal hasar ile 177 can kaybına neden olmuş, yıkık ve ağır hasarlı bina oranı \%30'u bulmuş, bunların çok büyük bölümü de kırsal yapılardan oluşmuştur (Karaşin, Karaesmen, 2005).

2003 Buldan/Denizli Depremi, Sarıgöl-Buldan-Yenicekent arasında, 23 Temmuz 2003 günü 5.3 büyüklügünde ve 26 Temmuz 2003 günü 5.1, 5.5 ve 5.0 büyüklüklerinde 4 ayrı deprem olarak meydana gelmiştir. Buldan depremleri sonucu Buldan içesi ve yakın çevresinde Kerpiç ve yığma yapılarda ve Bölmekaya köyü ile Yenicekent beldesindeki camilerde hasarlar meydana gelmiştir. Betonarme yapılarda kayda değer hasar bulunmamakla birlikte, Buldan ilçesi yakınında inşaatı devam eden prefabrik fabrika binasında hasarların varlığı gözlenmiştir (Kumbasar vd, 2006). 
2004 Erzurum Depremi, 27.03.2004'te 5,1 büyüklüğündeki Çat ve takip eden günde 5,3 büyüklügüundeki Aşkale depremlerinden oluşmaktadır. Toplam 9 hayat kaybı olmuş, bunlardan 8' i Küçükgeçit köyünde meydana gelmiştir (Şimşek, 2005).

2005 Hakkari Depremi, 25 Ocak 2005 tarihinde ard arda gelen, büyüklüğü 4,2 ile 5,5 arasında değişen 4 ana depremden oluşmuştur. Sütlüce mezrasında 2 yurttaşın ölümüne, toplamda 510 yapıda ağır hasar, 620 yapıda orta hasar, ve 550 yapıda az hasar oluşmasına neden olmuştur. Ağır ve orta hasar gören yapıların \%90' 1nın hiçbir mühendislik hizmeti görmemiş kırsal yapılar olduğu tespit edilmiştir. Yapılar genelde moloztaş ile çamur harçlı toprak, kerpiç ve taşıyıcı olmayan, dayanımı düşük ponzadan imal edilen boşluklu briketlerle yapılmıştır (Sevmiş, 2005).

2010 Elazı̆ depremi, 8 Mart 2010'da Elazı̆̆'ın Karakoçan ilçesine bağlı Başyurt beldesinde 6.0 büyüklügünde meydana gelmiştir. Depremde çoğu yığma yapı olmak üzere yaklaşık 390 evin ağır hasar aldığı belirlenmiştir (Tokgöz, Can, 2011).

\section{Depremler Sonrası Görülen Yığma Yapı Hasarlarının Sınıflandırılması ve Öneriler}

Yığma yapılar "rijit" yapılardır. Doğal Titreşim periyotları kat adetlerinin 0,05 ila 0,07 katı olarak verilebilir. 4 Katlı bir tuğla yığma yapının periyodu 0.25 sn kadardır. Sönüm oranları da düşüktür. Kritik sönüm oranı \% 1-2 kadardır. Ancak çatladıktan sonra periyotları uzar ve sönüm oranları yükselir.

Kısa periyotlu olmaları nedeni ile uzak depremler yığma yapıları pek etkilemez. Kısa periyotları nedeni ile depremin merkezine yakın bölgelerde en büyük yer ivmesi olarak uç ivmesi gibi bir ivme ile zorlanır (Bayülke, 2011). Bu bilgilerinde 1şı̆̆ında, DBYBHY-2007'de yığma yapıların boyutlandırılması ve donatılması ile ilgili kurallar konulmuştur. Yığma binalar için kat yüksekliği, deprem bölgelerine göre kat adetleri, binaların simetrisi ve düzeni ile ilgili konstrüktif kurallar mevcuttur. Ancak bunların hayata geçirilebilmesi için öncelikle kırsal kesimlerde mühendislik hizmetlerinin sağlanması gerekmektedir. Çünkü bu tür binalar, genellikle deprem yükleri hesaplanmadan, gerekli detaylara önem verilmeden bilinçsizce yapılmaktadır (Çırak, 2011). Aşağıda, geniş bir literatür taraması yapılarak, deprem sonrası yığma yapı hasarları gruplandırılmış ve yığma yapı davranışını iyileştirmeye yönelik temel maddeler çıkarılmaya çalışılmıştır:

\subsection{Ağır çatılar}

Özellikle az gelişmiş ülkelerde kırsal kesimde çatı toprak olarak yapılmakta ve her mevsim bu çatılar üzerine yeni toprak tabakası serilerek sıkıştırılmakta ve çatı iyice ağırlaşmaktadır. Bu ağır çatının deprem esnasında kullanıcıların üzerine göçmesi büyük felaketlere neden olmaktadır (Korkmaz vd, 2005). Şekil 1.a 'da deprem sonrası böyle bir dam hasarı görülmektedir. Evlerin ağır çatı kütleleriyle kapatılmasının nedenlerinden biri, kışları evlerin içinin sıcak, yazları da serin olmasını sağlamaktır. Ancak bu tür çatılar deprem anında, duvarların düzlem dışı ve düzlem içi yönünde büyük bir kuvvetle itilmesine ve deprem anında binanın zayıf yönündeki duvarlarının ve/ve ya zayıf duvarlarının büyük bir kuvvet ile yıkılmasına sebep olmaktadır (Gölalmış, Türer, 2005). Daha detaylı olarak açıklamak gerekirse, yapıların çatı kaplamasında kullanılan ağır malzemeler, yüksek ataleti nedeniyle dinamik deprem etkileri sonucu aşırı yatay deprem yüküne maruz kalıp yapı çatısını ve tavanını ayakta tutan duvarların üst kısımlardan duvar düzleminin dışına doğru ötelenmesine ve çekmeye dayanıksız olan bu duvarların ve taşıdıkları çatının yapı içine yıkılmasına neden 
olmaktadır. Çatı kaplamaları yağışlar sonucu aktığı için, üstteki $10-20 \mathrm{~cm}$ lik bölümü ortalama iki senede bir yeniden toprakla doldurulmaktadır. Çatılar, yan yana dizilmiş ağaç gövdeleri üzerine oturtulan yaklaşık $0,5-1 \mathrm{~m}$ kalınlığında ve periyodik olarak doldurularak sıkıştırılmaya çalışılan toprak damlar olarak yapılmaktadır (Şimşek, 2005). Sikıştırma işlemleri, "loğ" denilen taş silindirlerle yapılmaktadır. Ağır çatı uygulamasından nispeten vaz geçmiş bazı kırsal bölgeler de bulunmaktadır. Örneğin 22 Mayıs 1971 depremi dolayısıyla ilk kez dikkatle incelenmiş olan Bingöl kırsalında, o dönemlerden bu yana tek anlamlı değişiklik, ağır toprak damlar yerine, biraz daha hafif ot örtülü ve ince saç- teneke kaplı çatıların yapılmış oluşudur (Şekil 2. 1.b.c.) (Karaşin, Karaesmen, 2005).
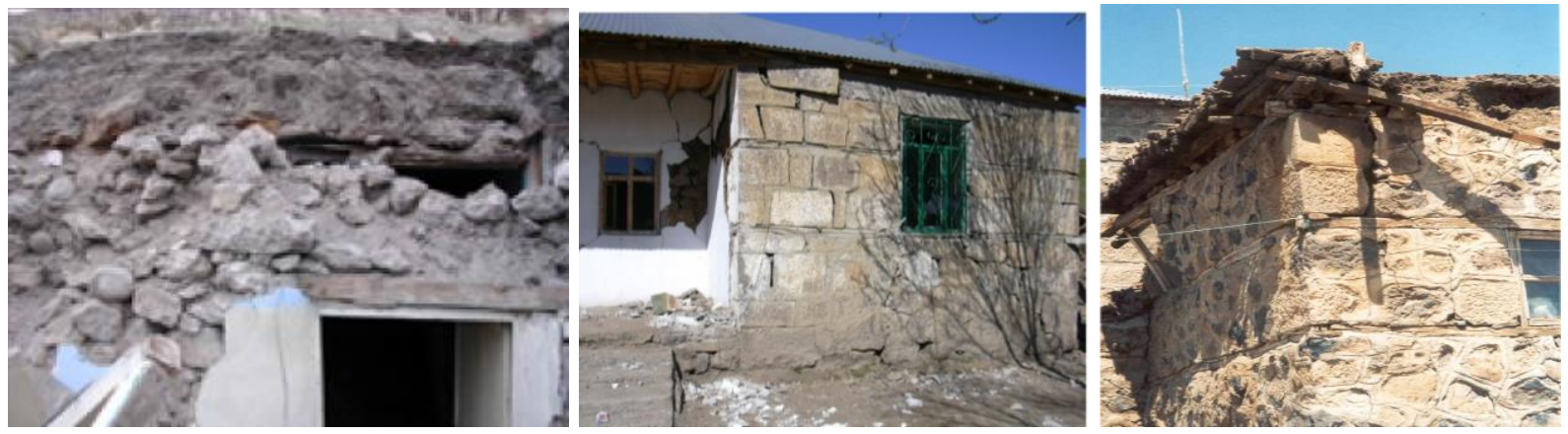

Şekil 2.1. (a) Kalın toprak damlı kırsal yapı hasarı (2004 Erzurum depremi) (Şimşek, 2005) (b) Hafif ot örtülü ve ince saç- teneke kaplı çatılı bina (c) Ağır toprak damlı bina (2003 Bingöl Depremi) (Karaşin, Karaesmen, 2005)

\subsection{Duvar altı hatılları}

Yığma duvarlı basit binaların deprem davranışı genelde zayıf olmakla birlikte, çeşitli önlemlerle bu davranışı ve strüktürün toplam dayanımını yeterli düzeye çıkarma olanağı vardır. Dış ve iç duvarlar üzerinde en basitiyle ahşaptan bile olsa binayı dolaşan ve kuşatan duvar altı ve üstü hatıllar yerleştirmek bu önlemlerden biridir (Karaşin, Karaesmen, 2005). Zira duvar altı hatılı olmayan yığma yapılarda, deprem etkisi ya da zemin sorunları nedeniyle zemine yükler yer yer öbekleşerek tekil yüke yakın bir zorlamayla etkiyebilmektedir. Duvar altı hatılı bu yüklerin zemine nispeten yayılı olarak gelmesini sağlamakta, duvar bütünlüğünü alttan da desteklemekte ve yapı zemin etkileşimini düzeltici olumlu bir etken olarak karşımıza çıkmaktadır. Şekil 2. 2.' de duvar altı hatıl kullanmadaki eksiklik hemen görülmektedir. Duvar altı hatıllı ve daha düzgün bir taş yığma duvar yapı dokusuna sahip binalar depremi nispeten az hasarlı atlatabilmektedirler.
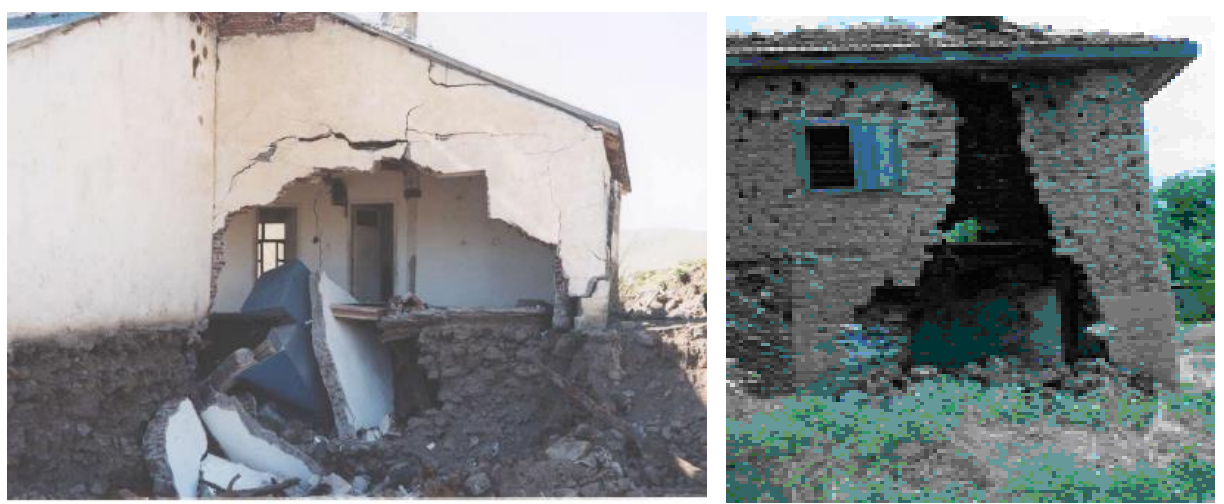

Şekil 2.2. (a) Gevşek zeminli ve duvar altı hatılsız yığma bina (2003 Bingöl depremi) (Karaşin, Karaesmen, 2005) (b) Derzleri üst üste gelen dayanıksız geleneksel kerpiçle üretilmiş duvar altı hatılsız kırsal yapı hasarı (2010 Elazı̆̆ depremi) (Binici vd, 2010). 


\subsection{Duvarın düzlem dıșı zorlanması ve duvar üstü hatılları}

Depreme maruz yı̆̆ma yapılarda düzlem içi yüklenen duvarın deprem davranışı, doğal olarak düzlem dışından farklı olmakta, bunun için de düzlem içi ve dişı yüklemelerin nasıl olduğunun bilinmesi önem kazanmaktadır. Yığma yapı davranışları, deprem hasarlarına bakılarak kolayca irdelenebilir. Yığma ya da dolgu duvarlar, en üst katlarda ve düzlem dış1 kırılmaktadır. Zira yığma duvarın düzlem içi kırılması, duvarın ezilme dayanımına yakından bağlıdır. Oysa düzlem dışı kırılma, duvarın eğilmeye çalışması sonucunda oluşan çökme gerilmelerine bağlıdır. Yığma duvarın düzlem dışı dayanımının, düzlem içi dayanımına göre daha küçük olduğu ve kırılmaların düzlem dışı olduğu, deprem hasarlarından açıkça görülmektedir (Kanıt vd, 2005). Yığma yapı duvarlarında, üst kısımda yeterli rijitlikte döşeme, lento bağlantısı yapılmamışsa, düzlemlerine dik yönde de hasar görürler. Duvarlarda su basman, kapı, pencere hatılı ve döşeme hatılı olmak üzere yatay bağlantılar tekniğine uygun yapılmamışsa depremden zarar görmeleri çok yüksek olasılıktır (Çırak, 2011). DBYBHY-2007' ye göre, betonarme kat döşemelerinin duvarlara oturdukları yerlerde en az duvar kalınlığ 1 kadar derinliği olan bir betonarme hatıl olmalıdır. Bu ayrıntı betonarme kat döşemesinin "rijit" davranmasını destekler. Betonarme hatıllar tuğla duvardan daha "sünek" ve yüksek dayanımlı elemanlardır. Duvarlarda yatay deprem yüklerinin oluşturacağı çatlakların ilerlemesini, duvarın dağılıp hem yatay hem de düşey yük taşıma gücünü kaybetmesini önlerler (Bayülke, 2011). Ayrıca üst başlarından yeterli biçimde bağlanmamış duvarlar ters pandül gibi, bahçe duvarları gibi, serbest durmaktadırlar. Özellikle geniş açıklıkları olan okul, cami gibi büyük hacimli alanlarda bu durum daha da önemli olmaktadır.

\subsection{Duvarlarda oluşan çekme- kesme zorlanmaları}

Bir önceki madde ile ilişkili olarak denebilir ki, yığma yapılar, çekme gerilmelerine karşı zayıftır ve güç tükenmesini bu gerilmeler kontrol eder. Çünkü yığma yapıyı oluşturan taş, tuğla, kerpiç harç ve beton gibi malzemelerin basınç dayanımı yüksek, çekme dayanımı düşüktür. Bu maddeler gevrek malzemeler olduğu için basınç ve çekme etkisine maruz kaldıkları zaman çok az bir deformasyona uğrarlar. Dolayısıyla, depremden meydana gelen yatay kuvvetler duvarları kesme kuvveti ile zorlar (Çırak, 2011). Bu zayıflık duvarda donatı kullanılarak giderilmeye çalışılır. Ancak bu tür donatılı duvar uygulaması ülkemizde yaygın değildir. Özellikle, küçük yerleşim birimlerinde donatısız yığma yapı yaygın olarak kullanılır (Celep, Kumbasar, 2004). Depremde, yığma yapılarda duvarda çatlama veya kısmi yıkılma olabilir. Çünkü genellikle, değinildiği üzere, yığma yapılarda kullanılan duvar malzemesinin çekme dayanımı, harcın ise kayma dayanımı düşüktür. En önemli hasar nedeni, deprem etkisiyle duvarlarda oluşan kayma gerilmeleri dolayısıyla çekme gerilmelerinin meydana getirdiği çatlak, ayrılma ve dağılmadır. Ayrıca, yığma yapılar ağır ve rijittirler. Dolayısıyla çok büyük deprem kuvveti oluştururlar. Yığma yapının çekme ve basınç altındaki sünek olmayan davranışı, yapının önemli bir plastik şekil değiştirme göstermeden aniden göçmesine neden olur (Celep, Kumbasar, 2004). Deprem kuvvetlerinden veya zeminde meydana gelen değişikliklerden dolayı doğan çekme gerilmelerini karşılayamayan taşıyıcı elemanlarda çekme ve kayma çatlakları meydana gelmesi doğaldır. Deprem hareketiyle birlikte bu çatlakların yönleri veya çatlak şekilleri yapının işçiliğine, kullanılan malzemelere ve duvarlardaki boşluk alanlarına göre değişiklikler gösterir. Bu çatlaklar genellikle pencere ve kapı boşlukları çevresindeki bölümlerde meydana gelebilir. Şekil 2.3, 4, 5 ve 6 da yığma duvar hasarları görülmektedir. 

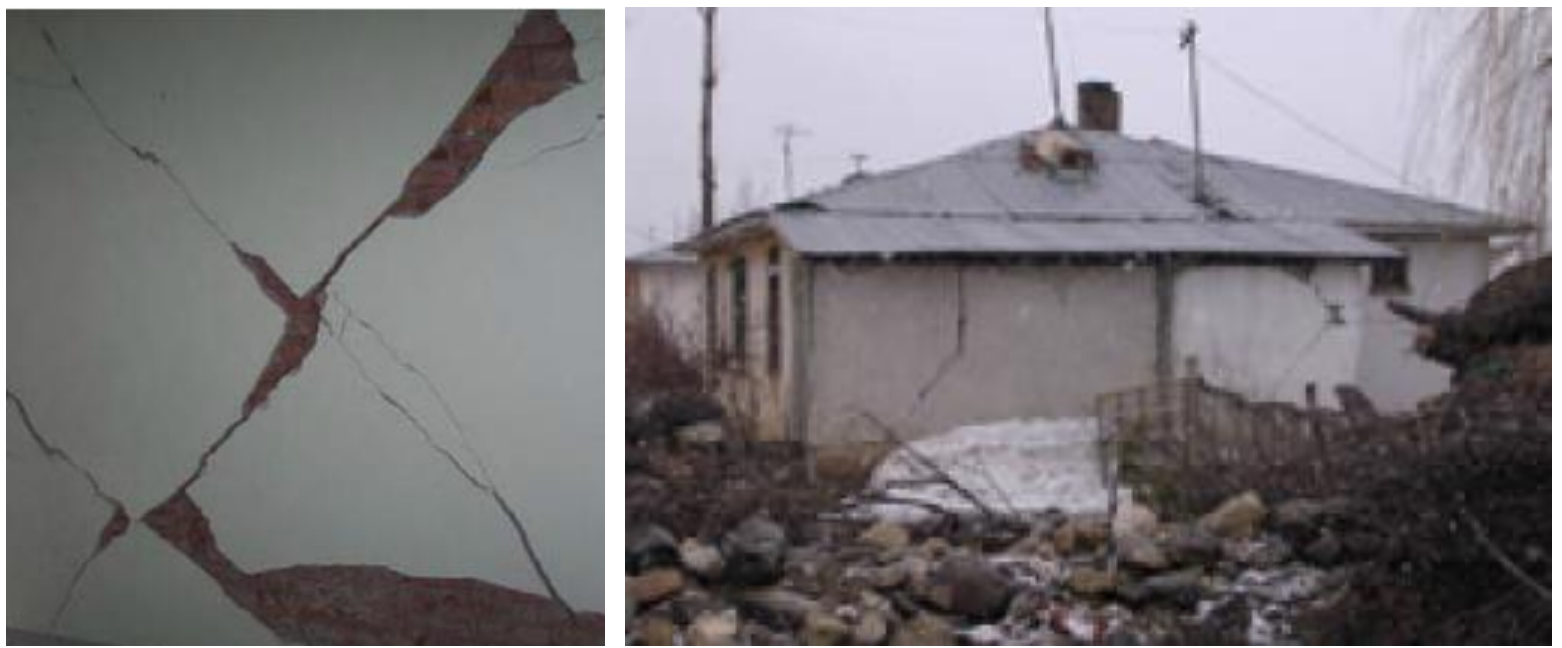

Şekil 2.3. (a) Yığma duvarlarda oluşan tipik kesme çatlağı (Doğangün vd, 2008) (b) Çayköy'de 84 Balkaya depreminden sonra devlet tarafından yaptırılan yığma binadaki duvar hasarı (Şimşek, 2005)

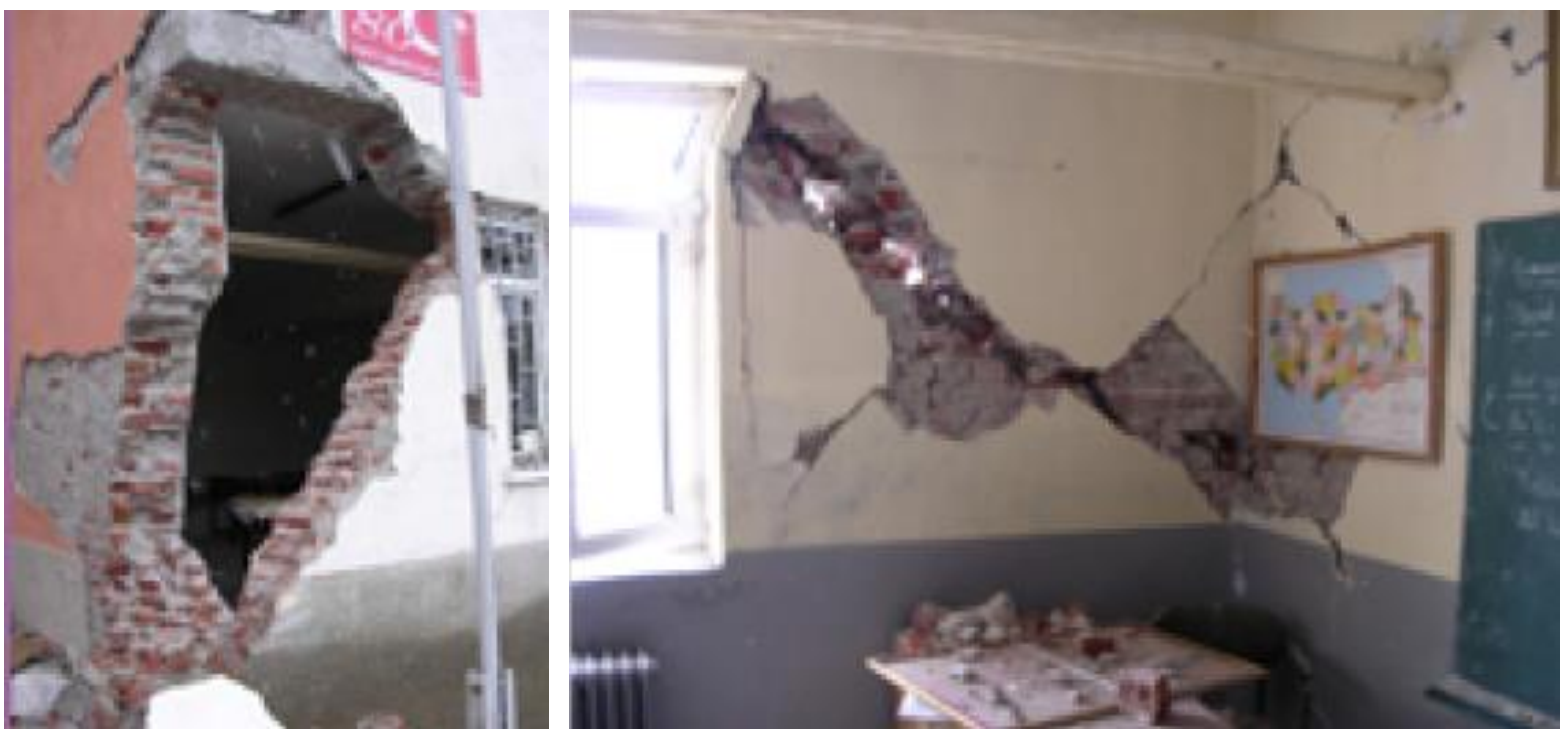

Şekil 2.4. Kandilli kasabasındaki yüksek hasarlı yığma okul binası (2004 Erzurum depremi) (Şimşek, 2005)
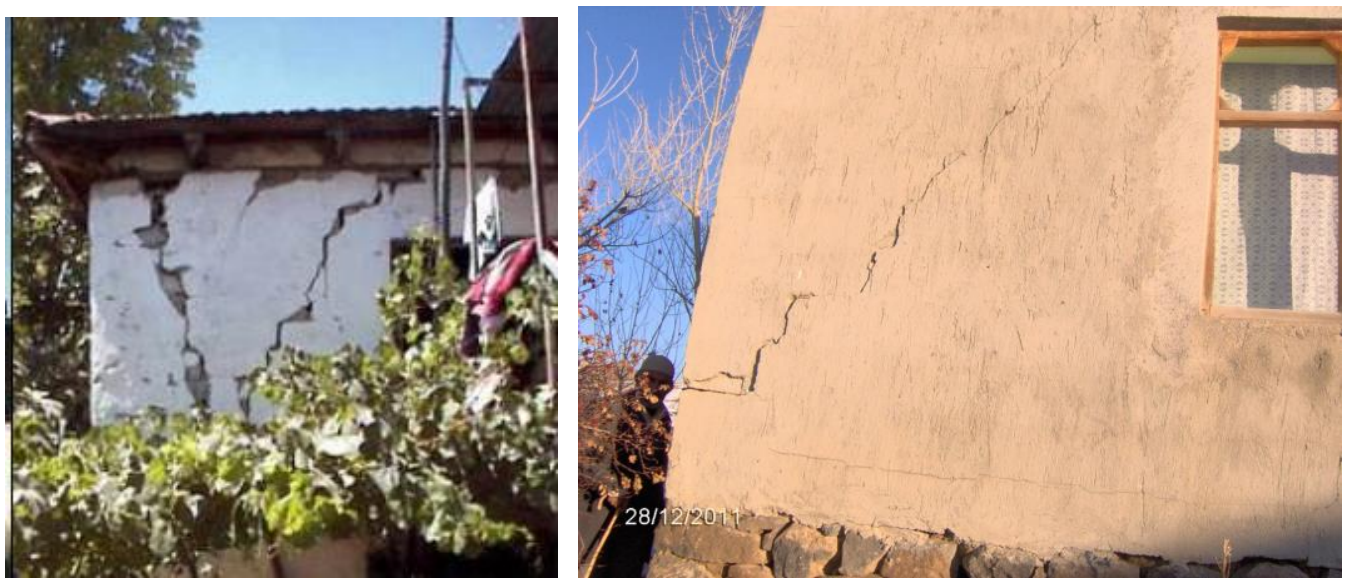

Şekil 2.5. (a) Yı̆̆ma yapılarda görülen duvar hasarları (1992 Erzincan depremi) (Çırak, 2011) (b) Duvar ayrışması (2012 Van depremi) (Alıcıŏglu, 2012) 


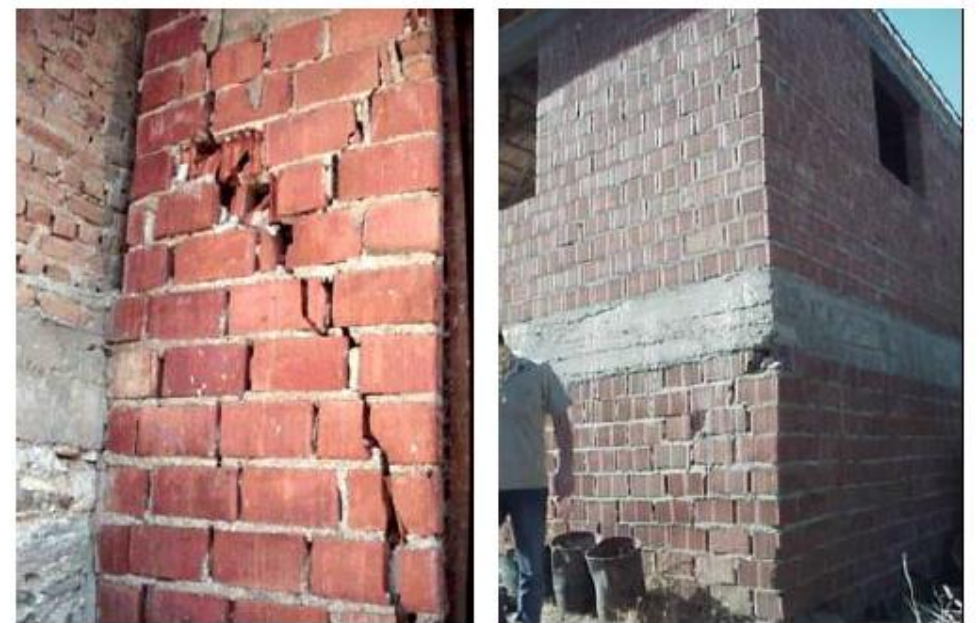

Şekil 2.6. Yı̆̆ma yapıda oluşan kesme etkili duvar hasarları (PÜ, 2003)

\subsection{Rijit köşe bağlantısı}

Özellikle 3. maddede belirtilen düzlem dış1 zorlanma ve 4. Madde de belirtilen yatay deprem yüklerinin oluşturacağı yatay ötelenmelere karşı davranış düzgünlüğünü sağlayacak başka bir temel unsur ise, köşe bağlantılarının sağlam ve rijit yapılmasıdır. Depremler sonrası göçen yığma binaların bir kısmında köşe rijitliğginin kurulamadığı dikkat çekmektedir. Buna karşılık düzensiz de yapılmış olsalar köşeleri iri taşlardan oluşmuş evlerde hasar daha sınırlı kalmıştır. Örneğin Şekil 2. 7a.' da zayıf ve gevşek köşe bağlantısı etkisiyle yıkılan yığma bina görülürken, Şekil 2. 7.b' deki köşe detayı, yarı çözüşmeye uğramış haliyle bile en azından can ve mal kaybı yaratabilecek bir büyük hasarın önünün alınabileceğgine işaret etmektedir (Karaşin, Karaesmen, 2005). Bu nedenlerle, özellikle yığma yapı duvarlarında köşe bağlantıları iyi yapılmalıdır. Planda duvar düzeninin simetriden ayrılmamasına dikkat edilmeli, gerekli konstrüktif kurallara uyulmalıdır. Yapım aşamasında eğer birbirinden farklı boyutlara sahip yapı elemanları kullanılıyorsa, birleşim bölgelerinde büyük olan elemanların kullanılmasına ve duvar örüm tekniklerine dikkat edilmelidir. Ayrıca yapı elemanı olarak mümkün olduğunca düzgün yüzeye sahip olanlar seçilmelidir (Çırak, 2011). Depremlerde yapılara her iki asal doğrultularında kuvvetler gelmektedir. Bu iki yönlü yükleme altında yığma yapı köşesinin durumu farklı hareketler gösterir ve birbirini iter. Eğer duvarlar köşede iyi bağlanmamış ve hatıl ya da tavan döşemesi yoksa duvarlar köşede birbirlerini düzlemleri dışına doğru iterek hasarların oluşmasına sebep olur. Şekil 2. 8, 9, 10 ve 11' de köşe hasarları görülmektedir. 


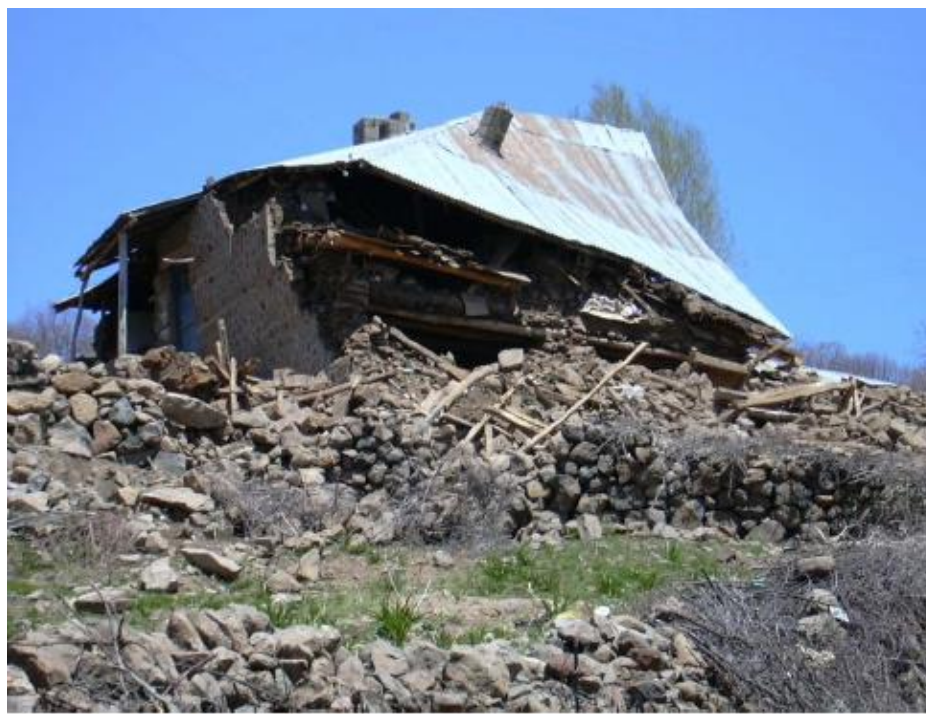

Şekil 2.7. (a) Zayıf ve gevșek köșe bağlantılı bina Bingöl depremi) (Karaşin, Karaesmen, 2005).

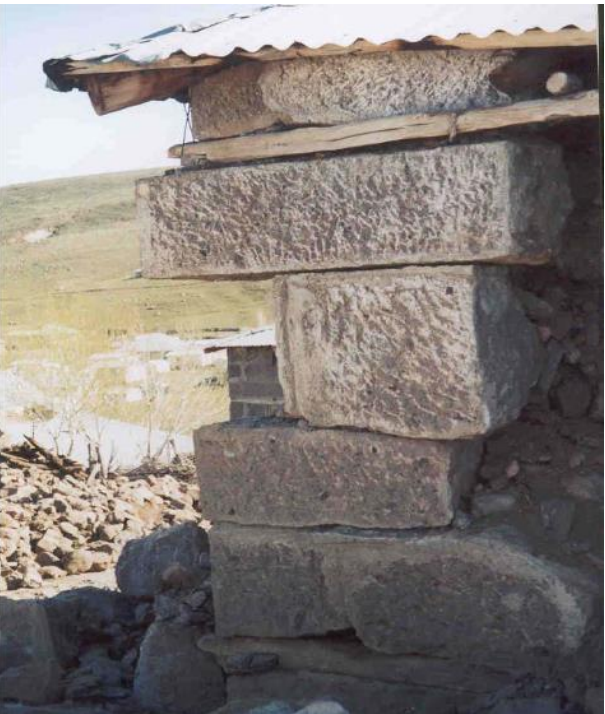

(b) Rijit yapılı köşe bağlantısı (2003
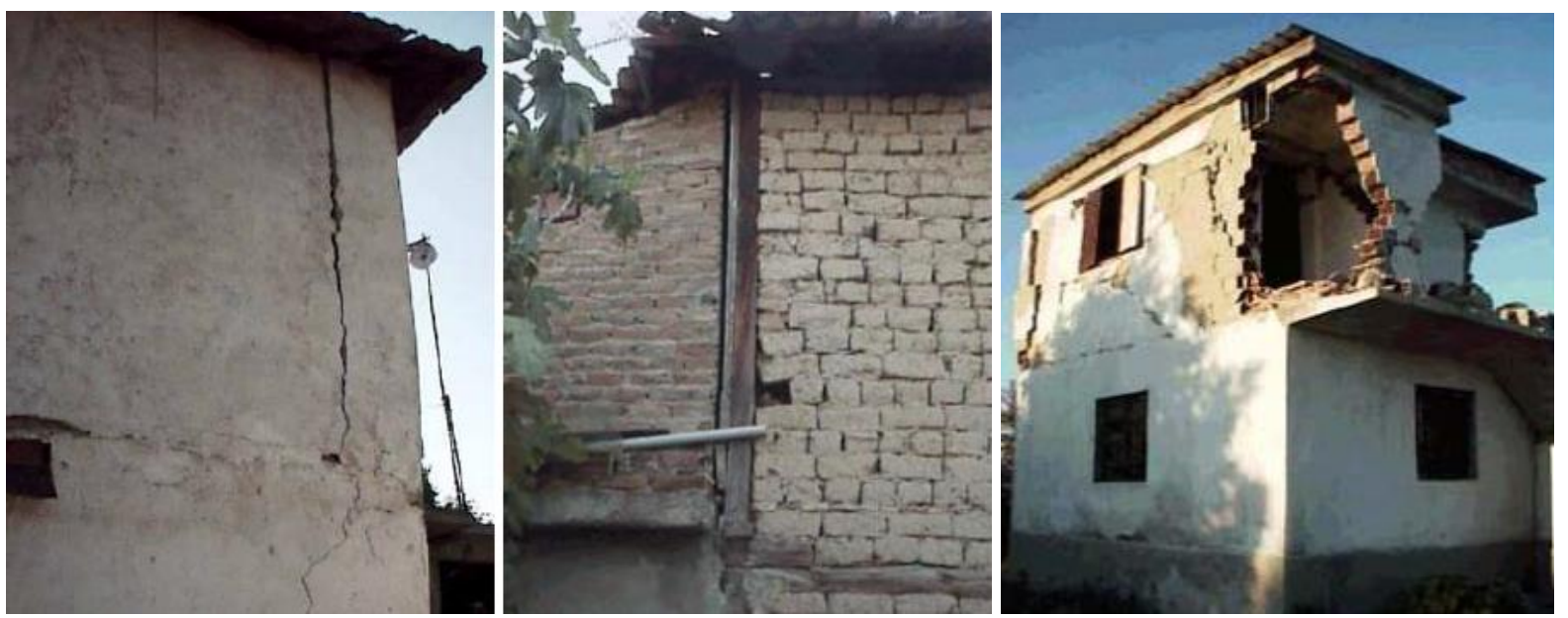

Şekil 2.8. Yatay ötelenmeden dolayı köşe noktalarında oluşan ayrışmalar ve köşe hasarları (2003 Buldan/ Denizli Depremi) (PÜ, 2003).

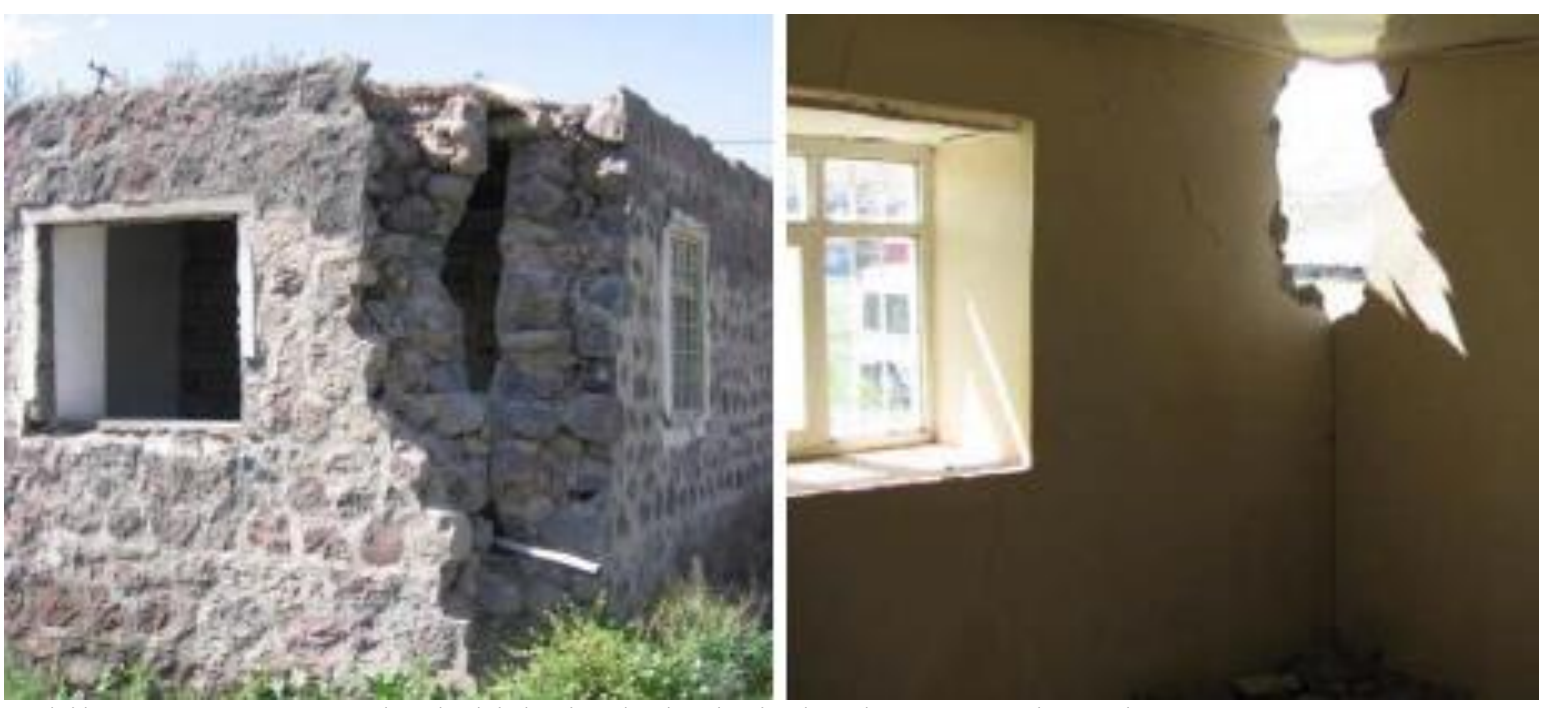

Şekil 2.9. Yığma yapılarda birleşim bölgelerinde oluşan ağır hasarlar (Bayraktar vd, 2007). 

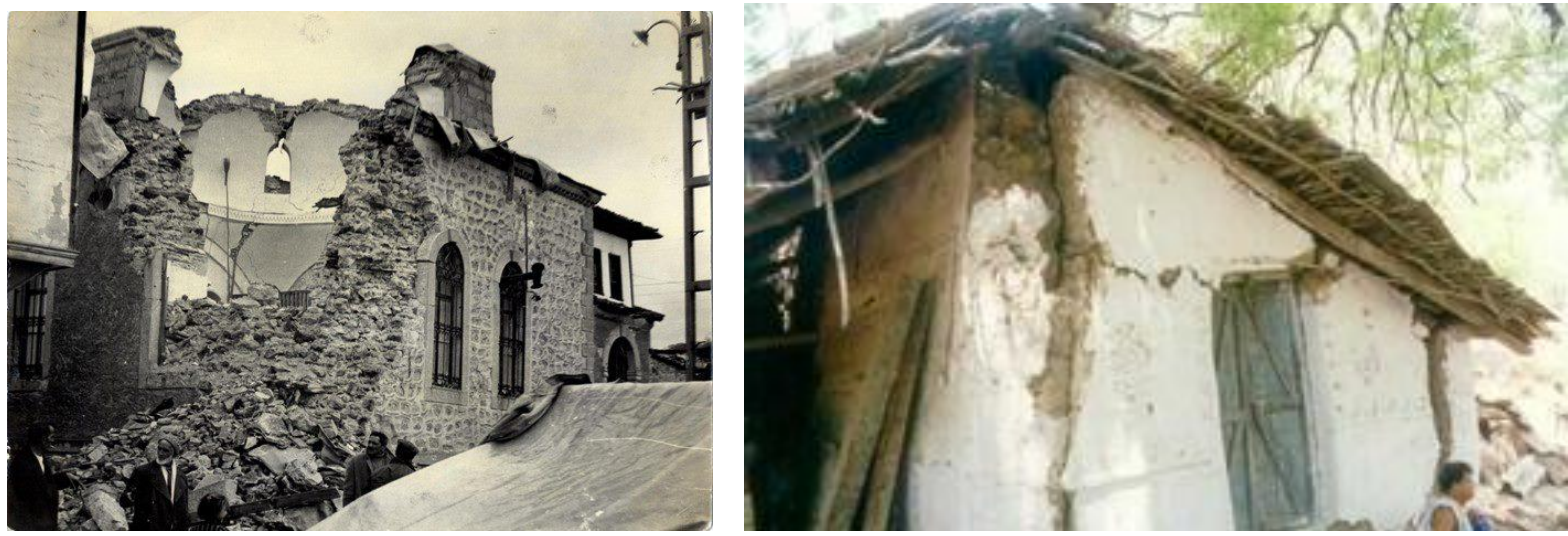

Şekil 2.10. (a) Yığma yapıda köşe hasarı (1970 Gediz depremi) (Pınar, 2004). (b) Yığma yapıda köşe ayrılması (Arun, 2005).
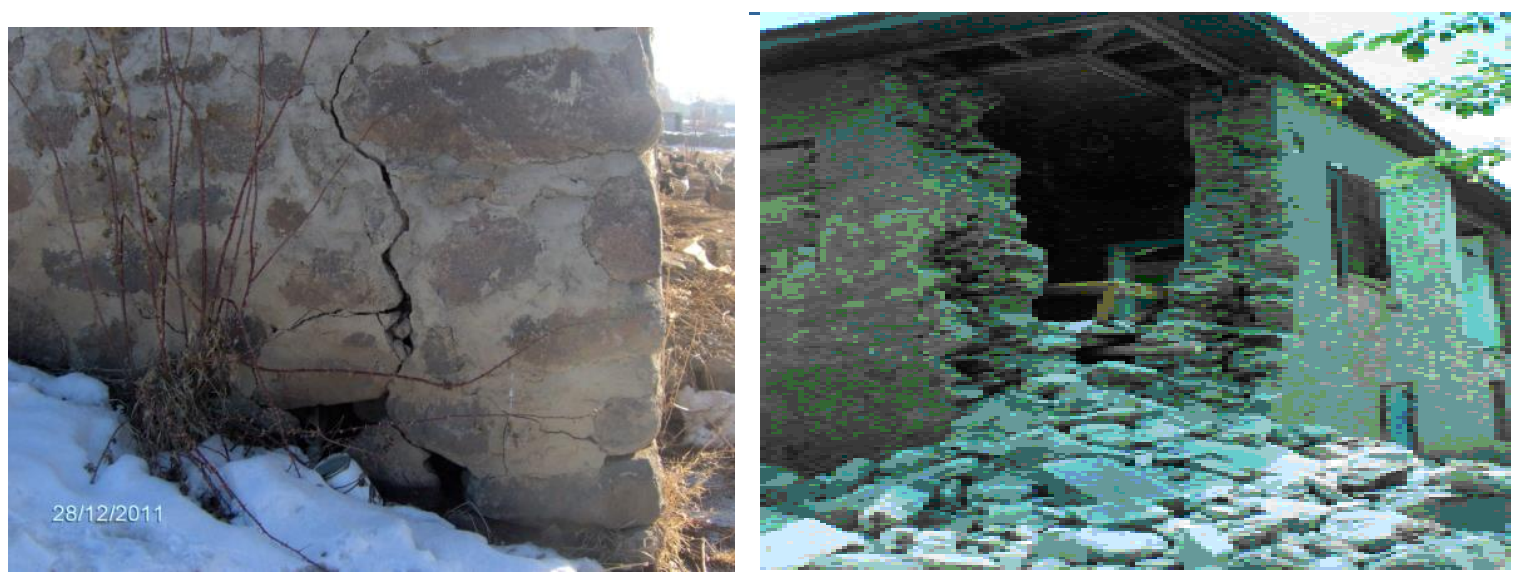

Şekil 2.11. (a) Köşe ayrışması (2011 Van depremi) (Alıcıuğlu, 2012). (b) Derzleri üst üste gelen dayanıksız geleneksel kerpiçlerle üretilen kırsal yapıda köşe birleşim hasarı (2010 Elazı̆̆ depremi) (Binici vd, 2010).

\subsection{Cephe boşlukları ve yığma- karkas taşıyıcı sistem etkisi}

Yığma yapılarda yapılan bir başka uygulama hatası ise, yapının sokağa veya caddeye bakan cephesinde, büyük açıklıklı kapı ve pencere boşlukları bırakmaktır. Bu boşluklar, yönetmelikteki boşluk oranları ile çelişkili olduğundan, ön cephe betonarme kolonlara taşıttırılmaya çalışılmakta, bir nevi yarı karkas- yarı yığma bir sistem oluşturulmaktadır. Ancak bu durum aynı yapı içinde elastik özellikleri çok farklı iki değişik malzeme kullanılması nedeniyle yapıda rijitlik düzensizlikleri meydana getirmekte ve böylece deprem sırasında yapıda burulma etkilerinin oluşmasına neden olmaktadır (Çırak, 2011). Yı̆̆ma yapı diş cephesinde çok miktarda boşluk olduğunda depremde etkiyen kesme kuvvetlerinin taşınması için yeterli alan olmayacağı için, DBYBHY-2007'de, dış cephe boşluk oranları toplam cephenin \% 40'1 olarak sınırlandırılmıştır. Bu kurala uymayan yığma yapıların deprem hasarının daha çok olduğu pek çok depremde görülmektedir. Deprem dayanımı sağlayan bir başka kural pencere ve kapı boşlukları arasında yeterince geniş dolu duvarların olmasıdır. $\mathrm{Bu}$ duvarlar hem düşey yüklerin hem de yatay yüklerin taşınması için gereken alanları sağlar. Ayrıca geniş olmaları basınç ve kayma gerilmelerinin izin verilen miktarlarda olmasını da sağlayabilir (Bayülke, 2011). Şekil 2. 12' de cephe boşluğu etkileri görülmektedir. 

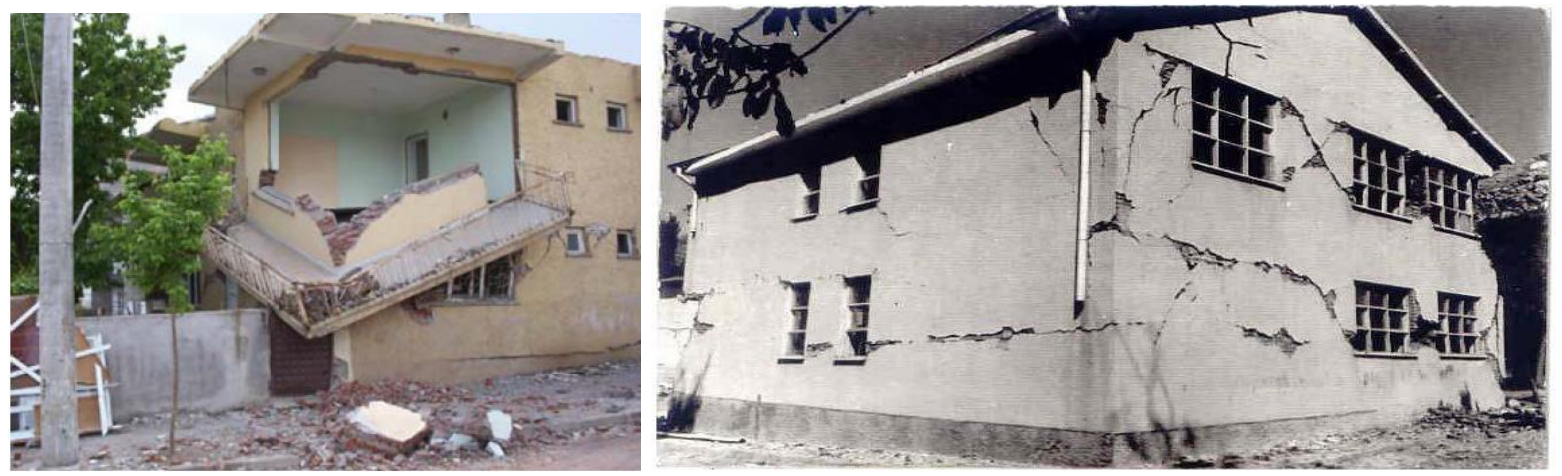

Şekil 2.12. (a) Yarı yığma- karkas sistemde cephe boşluğu ve konsol etkisiyle hasar oluşumu (Çırak, 2011) (b) Boşluk oranı yüksek ve az olan duvarlardaki hasar düzeyleri (1975 Lice depremi) (Bayülke, 2011)

\subsection{Duvar ve harç malzemesinin etkisi ve düşey- yatay ara hatıl kullanımı}

Yığma yapılarda yük aktarımı, kullanılan malzeme ve harç arasında olmaktadır. Yığma yapılar, kullanılan malzemenin özelliklerine göre farklı davranışlar sergileyebilir. Yı̆̆ma yapı hasarları, genellikle duvarda çatlaklar, temelde oturmalar ve kullanılan malzemenin bozulması veya şekil değiştirmesi şeklinde oluşur (PÜ, 2003). Özellikle duvar çatlakları, duvarda kullanılan malzemenin özelliğine göre de değişir. Tuğla ve dolu beton briket, hafif beton briket gibi malzemeler ve bunların bağlayıcı olarak harçlarla birlikte oluşturduğu duvarlar, homojen değildir. Doğal taşlarla örülmüş duvarlarda da aynı durum mevcuttur. Doğal taşlardan oluşan moloz taş duvarlarda derzler gelişigüzel bir şekildedir (Çırak, 2011).

Duvarlarda kullanılan bloklar Türkiye'de genel olarak pişmiş topraktan yapılmış tuğladır. Beton blok ya da boşluklu briket yapı az da olsa vardır ancak bunlar genelde tek kattan yüksek değildir. Yığma yapının bodrum ve temel duvarlarında taş kullanılmalıdır. Tuğla her ne kadar pişmiş de olsa su ve dondan etkilenmektedir. Sudan sıvanarak korunmalıdır. Topraktan su alabileceği için bodrum kat dış duvarları taş olarak yapılmalıdır (Bayülke, 2011).

Kırsal yapılarda ise genelde, en zayıf duvar malzemesi olan Kerpiç bloklar kullanılmaktadır. Ancak bunlarda bile düzgün bir üretimle hatırı sayılır basınç dayanımlarına ulaşabilmek mümkündür. Zira kerpiç bloklar için Fikret Gürdil (Gürdil, 1984) deneylerinde 28 günlük basınç dayanımı $17 \mathrm{kgf} / \mathrm{cm}^{2}$, Nejat Bayülke deneylerinde ise (Bayülke, 1990) 45 günlük dayanımı $30 \mathrm{kgf} / \mathrm{cm}^{2}$ bulunmuştur. Ancak Türkiye kırsal yapılarında kullanılan duvar malzemesine bakıldığında, İç Ege, Orta Anadolu, İç Çukurova'daki "kerpiç" malzemesinin, Doğu'ya doğru gidildikçe yerini taş’a bıraktığı görülür. Örneğin Bingöl köy ve kasabalarında maalesef çoğu harçsız iri taş duvarlı binaya sık rastlanmaktadır (Karaşin, Karaesmen, 2005). Erzurum bölgesi kırsalındaki yapıların büyük bölümü de, civardaki bir çok dere yatağından toplanan, yüzeyleri aşınarak yuvarlanmış ve yığma yapı inşaatında kullanılmaması gereken taşların çamurla birbirine bağlanmasıyla inşa edilmiştir. $\mathrm{Bu}$ tip yapılarda depreme dayanıksızlığın en önemli nedeni, taşların birbirine sadece normal çamurla bağlanmış olmasıdır. Bu malzemenin iklimsel nedenlerle yıllarca akması ve parçalanması, dayanımı zaten yeterli olmayan bu yapıştırıcı malzemenin tamamen etkisiz hale gelmesine neden olmaktadır (Şimşek, 2005).

Moloz taş duvarların dayanımı da çok zayıftır. Çamur harcın 1slak durumda bir miktar bağlayıcı özelliği vardır. Çamur kuruyunca bu özellik tümü ile kaybolmakta, kurumuş çamur 
taşların arasından akıp gitmekte ve birbirine çok küçük ve az sayıda noktada değen taşlar arasındaki sürtünme kuvveti, duvarın kesme kuvveti taşıma gücünün tek kaynağı olmaktadır. Bu sürtünme kuvveti de deprem sırasında yeteri kadar yük kaldıramayacağı için yığma yapılar yıkılmaktadır.(Şekil 2. 13) Kalın duvarın iç ve dış düzeyine konulmuş ve birbirlerine bağlantısı olmayan taşlar kolayca ayrılıp, özellikle dış duvar yıkılmaktadır (Bayülke, 2011).
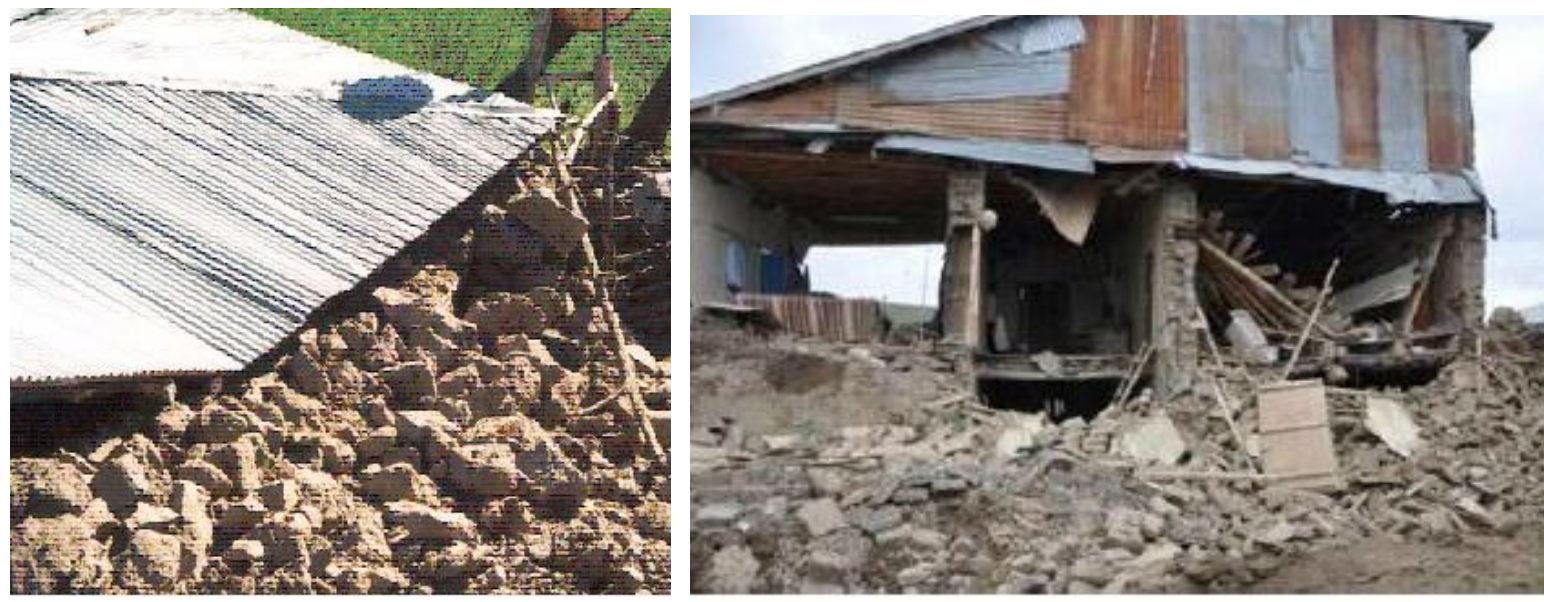

Şekil 2.13. (a) Moloz taşlar arasındaki çamurlar ıslakken bağlayıcı özellik göstermesine karşın kuruyunca bu özelliğini kaybeder (Batur, Kaplan, 2006) (b) Yıkılmış kerpiç ev (2010 Elazı̆̆ depremi) (Binici vd, 2010)

Yapay taşlardan oluşan duvarlarda basınç dayanımı, başta tuğla ve harcın basınç dayanımı gibi ölçülebilen parametrelere bağlıdır. Ancak, işçilik, derz kalınlığg, duvar boyutları gibi parametreler de dayanımı önemli derecede etkilemektedir. Ayrıca, yapım kusurları ve standart dışı blokların ve harcın kullanılması, derzlerin harçla doldurulmaması, duvarların düşeyden ayrılması, önemli yığma yapı hasar nedenleridir. Betonarme yapılarda olduğu gibi, yapım aşamasında işçilik, detaylandırma ve malzeme kalitesi yı̆̆ma yapılarda da oldukça önemlidir. Ayrıca yük aktarımının sağlıklı bir şekilde sağlanabilmesi için malzemeler arasında aderans sağlanmalıdır. Düşey ve yatay yönde yapılması gereken hatılların detaylarına dikkat edilmelidir. (Çırak, 2011) Zira düşey betonarme hatıllar, belli aralıklarla duvara dik koyulan duvarlar, kesişen duvarlar ya da destek ayakları gibi, çatlamış blokların hareketini sınırlandırmak için yararlıdır. Aksi halde, diğer olumsuz durumların da birleşmesiyle Şekil 2. 14a.' da görülen yıkımların oluşması kaçınılmazdır. Şekil 2. 14b.' de görülen düşey - yatay hatılların önemini vurgulamak için Şekil 2. 15.' de verilen, benzer destek elemanlarına sahip hımış ve göz dolma yapılar örnek olarak gösterilebilir. Anadolu'da inşa edilen hımış ve göz dolma yapılar, kagir blokların ahşap düşey ve yatay elemanlar arasında düzenlendiği karma yapım sistemli yapılardır. Deprem kuvvetleri karşısında sık düzenlenmiş ahşap dikme ve kuşaklar, kagir kısımda $\mathrm{X}$ çatlakları oluşmasını önler. Burada kagir kısmın yok olması duvarın göçmesine neden olmaz (Arun, 2005). 

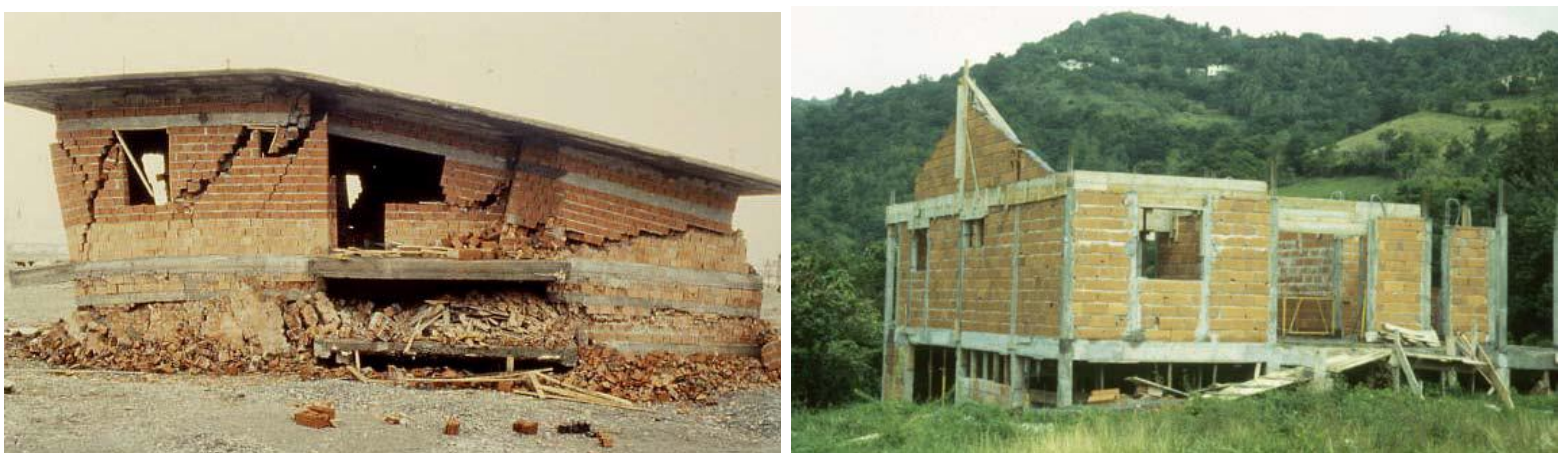

Şekil 2.14. (a) Düşey hatıllarla sınırlandırma yapılmamasına rağmen çok katlı inşa edilmiş bir yığma yapı hasarı (b) Düşey hatıllar (Arun, 2005).
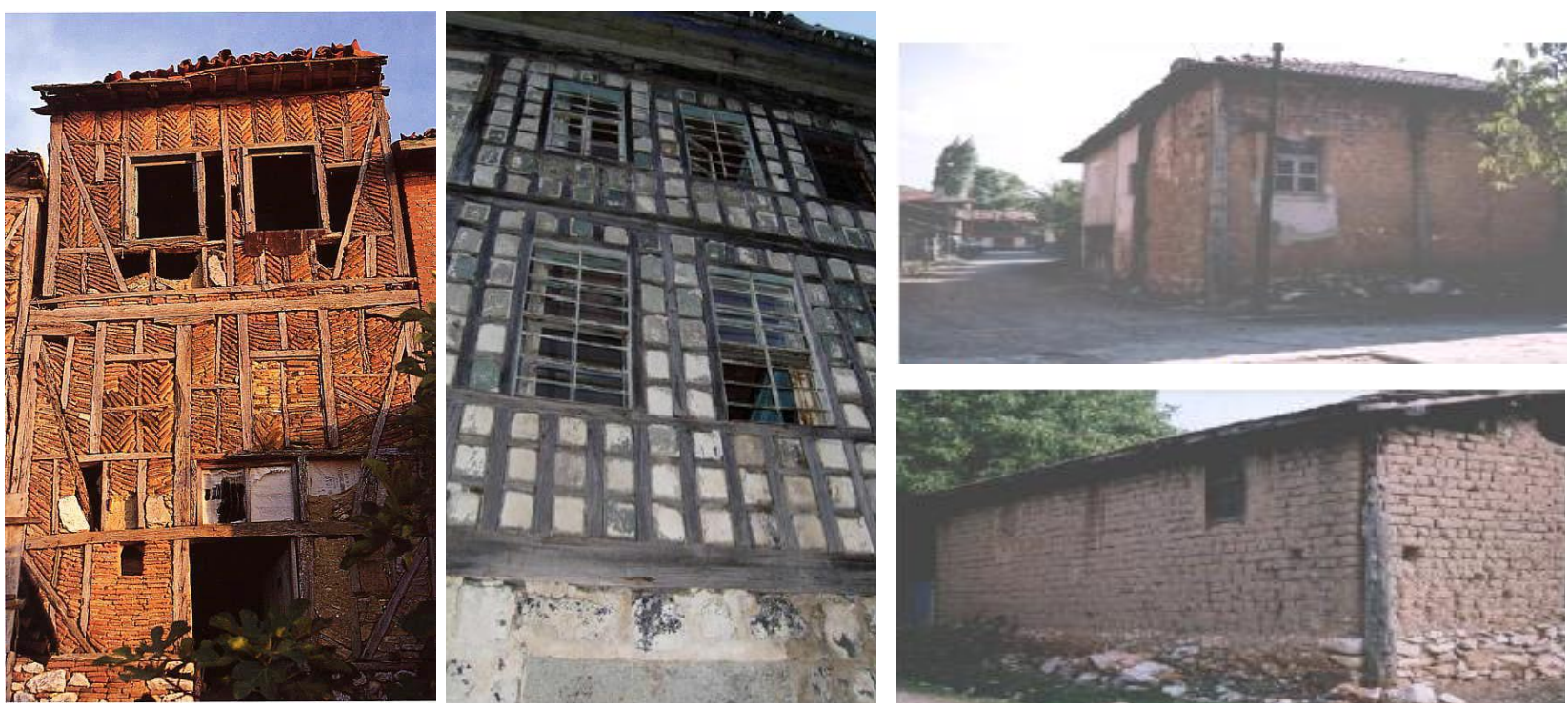

Şekil 2.15. (a) Hımış (b) Göz dolma yapılar (Arun, 2005). (c) Ahşap dikmelerle desteklenmiş kerpiç yapılar (Koçu, Korkmaz, 2004).

Yığma yapı duvarlarında çimentolu kireç harcı kullanımı yaygındır. Kireç, harcın sertleşmesini ve su kaybını yavaşlatmakta çimento ise dayanımı artırmaktadır. Duvarların örülmesi yavaş bir işlem olduğu için harcında yavaş serleşmesi uyumludur. Harcın en büyük sorunu iyi pişmemiş tuğlanın harcın suyunu emerek yeterince sertleşmesini ve dayanım kazanmasını önlenmesidir. İyi pişmemiş tuğlalar nedeni ile yeterli harç dayanımı sağlanmamaktadır (Bayülke, 2011).

Genellikle duvar basınç dayanımı, düşük basınç dayanımlı bloklarda blok basınç dayanımının \% 50'si, yüksek dayanımlı bloklarda \% 25 'i kadardır (Bayülke, 1992). Harç dayanımının duvar bloklarının dayanımından yüksek olması duvar basınç dayanımını çok az artırmaktadır. Buna karşılık aynı harç dayanımında daha yüksek dayanımlı blok kullanılması duvar basınç dayanımını daha yüksek bir oranda artırmaktadır. Doğru çözüm, yüksek dayanımlı tuğla ile yüksek dayanımlı harç kullanılmasıdır. Derz kalınlığı azaldıkça da duvar basınç dayanımı artmaktadır (Bayülke, 2011).

4. maddede belirtildiği üzere, yığma yapılarda deprem yükleri duvarlarda kesme gerilmeleri oluşturur. Tuğla yığma yapının deprem dayanımı büyük ölçüde duvarlarının kesme kuvveti taşıma gücüne bağlıdır. Duvar kayma dayanımı tuğla ile harç arasındaki yapışma (aderans) ve harç-tuğla ya da tuğla-tuğla arasındaki sürtünmeye bağlıdır. Genel olarak yüksek dayanımlı 
harcın kesme dayanımını artırdığı görülmektedir. Yine düşey delikli tuğlada boşluk oranının azalması da duvar kesme dayanımını artırmaktadır (Bayülke, 2011).

1970'li yıllara kadar yapılan yığma yapıların duvarlarında dolu "harman" tuğlası kullanılmıştır. Bu tür duvarlarda tuğlanın bütün üst ve alt yüzeyi harçla kaplıdır. Ayrıca tuğlanın üzerinde harçtan bir "kesme" kaması oluşturan bir harç cebi" vardır. Bu nitelikler, basınç dayanımı düşükte olsa harman tuğlasından yapılmış duvarlarda önemli boyutta bir kesme dayanımı sağlayabilir. Çok delikli fabrika tuğlalarında büyük boşluklar nedeni ile harç ile kaplı alan küçülmüştür. Bu tuğla ile harç arasındaki aderansı azalttığı gibi çatladıktan sonra harç-tuğla ve tuğla-tuğla ara yüzeyinde sürtünme ile kesme kuvveti taşınmasını da azaltmaktadır. Tuğla ya da beton briketlerdeki boşlukların düşük dayanımlı bir haç ile doldurulmuş olmasının kesme dayanımını artırdığı Deprem Araştırma Dairesi Sarsma Tablasında yapılan deneylerde gözlenmiştir (Bayülke, 1992).

\subsection{Temel oturmaları}

Yığma yapılar, temel oturmalarına karşı çok hassastırlar. En küçük temel oturması duvarlarda hemen gözlenir. Bunun nedeni yığma duvarın gevrek malzemeden meydana gelmesi ve bu malzemenin çatlamadan dayanabileceği elastik gerilme ya da yüklerin çok düşük olmasıdır. Dayanımı zayıf bir malzeme olduğu için kolayca hasar görür. Yı̆̆ma yapılarda, temeldeki oturmalar duvarda çatlaklara neden olur; duvarda oluşan her tür çatlak da taşıyıcı sistemi etkiler (Bayülke, 1980). Farklı oturma şekillerine göre farklı çatlaklar oluşur. Oturma çatlakları yapının temelinin daha çok oturduğu bölümler ile diğer bölümler arasındaki sınırları belirler. Yığma yapılarda çeşitli oturma çatlakları görülmektedir. Bir cephenin ortasındaki oturma köşelerden fazla ise oturma çatlakları temele yakın bölümlerde daha geniştir. Eğer köşeler, otaya göre daha çok oturuyorsa, eğik oturma çatlakları yukarıya doğru daha geniştir. Bir köşede oturma farklı ise üst taraftaki çatlak daha geniştir (Bayülke, 1992).

Yığma yapılarda oturma hasarının nedeni çoğunlukla sömellerin altındaki özellikle killi zeminlerin taşıma gücünün su kaçakları sonucu zayıflamasıdır. Yığma yapıların duvarlarına gelen düşey gerilmeler ile kullanılan sömel boyutları karşılaştırılınca zemine aktarılan gerilmelerin oldukça küçük değerlerde olduğu görülür. Eğer çok sı̆̆ temel yapılmamış ise yapının kendi ağırlığından dolayı oturma olasılığı azdır. Ancak kullanma suyu, kalorifertesisat suyu kaçakları gibi basınç altındaki sular ile kanalizasyon kaçakları ya da başka yeraltı su sızıntıları nedeni ile sömellerin altının boşalması ya da buradaki killi zeminin kohezyonunun azalması oturma hasarına yol açmaktadır. Özellikle plastisitesi yüksek ve geçirimsiz olan killi bir zeminde oturma yavaş olmakta ve uzun bir süre sonra ortaya çıkabilmektedir. Oturmaya yol açan su kaçağının giderilmesinden sonra kuruyan kilin büzülmesi ile oturmalar bir süre daha devam eder. Kurak mevsimlerinin sonuna doğru zeminin su içeriğinin azalması ile artan büzülme sonbahar mevsiminin başlangıcında en yüksek düzeyde oturma çatlakları oluşturmaktadır. Bu nedenle pek çok yapıda çatlakların mevsimsel olarak açılıp kapandığı gözlenebilir. Bununla birlikte gevşek zemine kurulmuş yığma yapılarda deprem etkisiyle oturmalar daha hızlı bir şekilde gerçekleşerek duvarların göçmesine yol açmaktadır.

\section{9. Çok boşluklu tuğla kullanımı}

Standartlara göre taşıyıcı tuğlalarda düşey delik oranı \% 35 ve daha az olmalıdır. Ancak genelde kırsalda kullanılan tuğlaların delik oranları en iyi koşullarda \% 45 dir. Delik oranı \% 60 kadar olan tuğlalarda kullanılmaktadır. Delik oranının artması ile duvarda düşey yük 
taşıyan alan küçüldüğü için duvar dayanımı azalmaktadır. Tuğladaki delikler arasındaki et kalınlığının azalması hatta delik biçimleri ve yerleri de tuğla blok ve dolayısı ile duvar dayanımını azaltmaktadır. \% 35 delikli blok tuğla daha ağır olduğu için taşınması ve duvara konulması, duvar örülmesi daha zor ve masraflıdır. Bu nedenle daha çok, karkas yapılarda bölme duvarı olarak kullanılması amacıyla delikli tuğlalar üretilmiştir. Bunların yığma binaların duvarlarında taşıyıcı olarak kullanılmaması gerekirken, değinildiği üzere, \% 60 kadar delik boşluğu olan tuğlalar dahi yığma yapılarda kullanılmıştır. Çok delikli blok tuğlada harç konulan yüzey çok azdır ve duvar çatladıktan sonra oluşacak sürtünme ile deprem enerjisi tüketimi için yeterli temas alanı da yoktur. 1995 Dinar depreminde alt iki katı harman tuğlası üst iki katı çok delikli olduğu için "televizyon" tuğla denilen bloklarla yapılmış çok sayıda yığma yapının üst katları yıkılmıştır (Şekil 2. 16a) (Bayülke, 2011) Erzincan ve Dinar Depremlerinde dolu tuğla ile yapılan yığma binalar oldukça az hasar görürlerken, hasar gören yığma yapıların hemen hepsi boşluklu tuğlalarla yapılmıştır. (İTÜ, 1992), (Bayülke, 2003). Dinar depreminde, önceden dolu tuğla ile yapılmış tek katlı evler üzerine yakın tarihlerde boşluklu tuğla ile yapılan ilave katlar dağılarak çökmüştür (Şekil 2. 2. 16b). (ODTÜ, 1995)
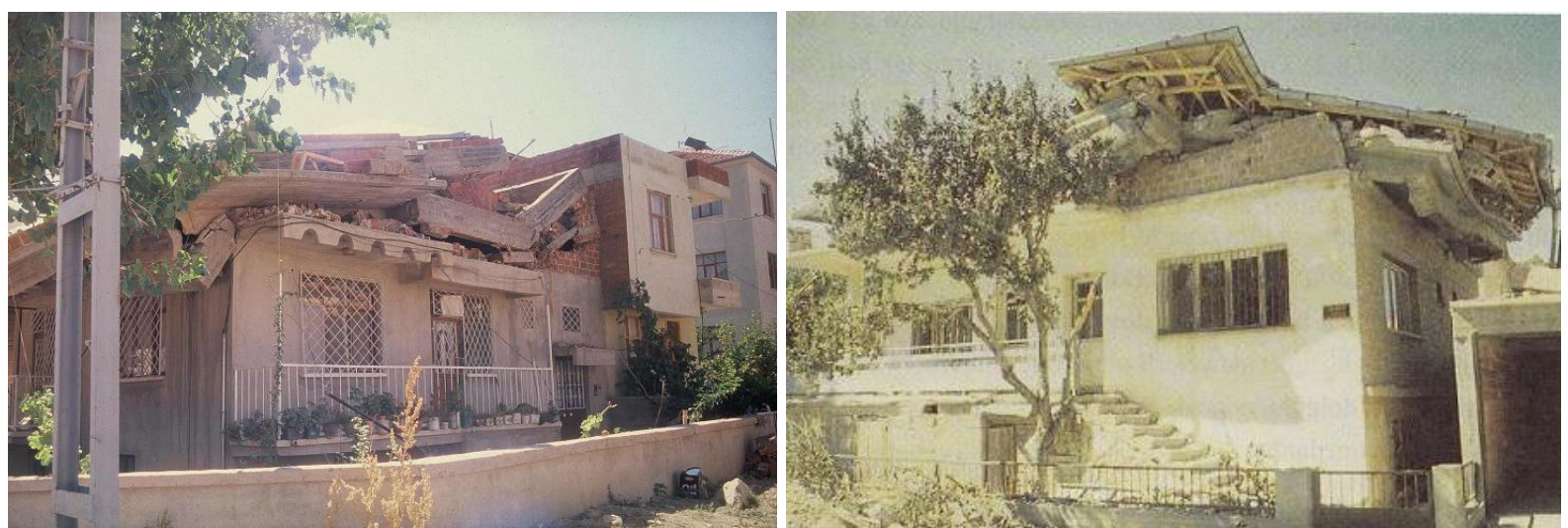

Şekil 2.16. (a) Üst katları televizyon tuğladan yapılmış ve yıkılmış yapı (1995 Dinar depremi) (Bayülke, 2011) (b) Üst katı boşluklu tuğla ile yapılmış yı̆̆ma binada deprem hasarı (1995 Dinar Depremi) (ODTÜ, 1995)

\subsection{Kalkan duvarı hasarları}

Depremler sonrasında taşıyıcı sistemi yeterli olduğu halde kalkan duvarı yıkılan ya da hasar gören bir çok yığma bina da vardır ( Şekil 2. 17.). Türkiye'de hatalı kalkan duvar sorunu tüm bina türlerinde vardır ve tüm belirginliğine rağmen bir türlü giderilememektedir. Örneğin Dinar Devlet Hastanesinin en önemli hasarı kalkan duvarının çökmesidir. Ancak binaya olan güvenin yitirilmesine yeterli olmuştur (ODTÜ, 1995) 

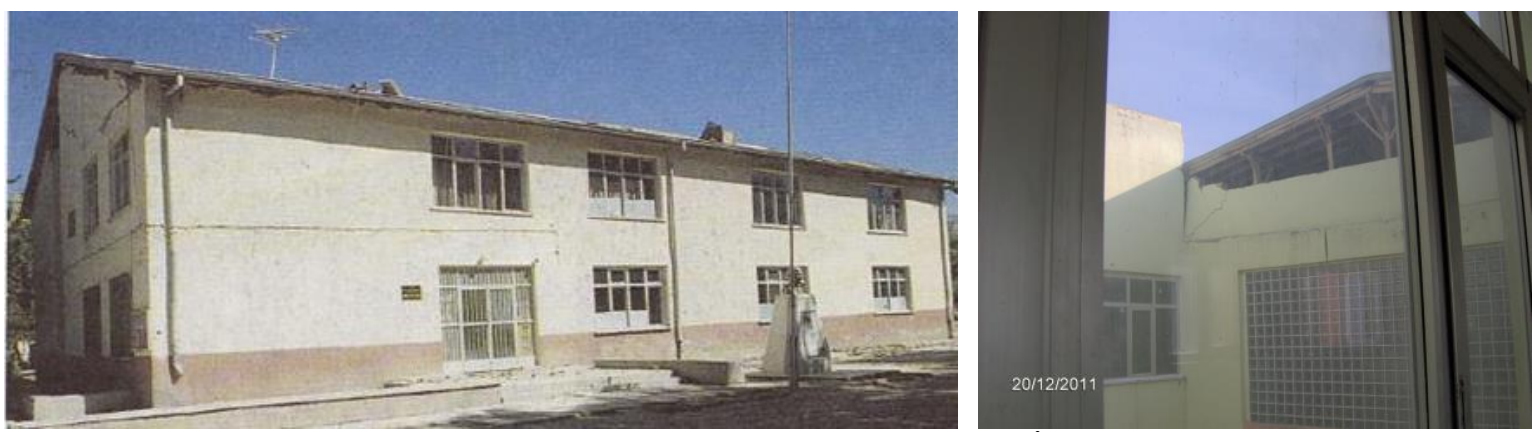

Şekil 2.17. (a) Yığma binada kalkan duvarı hasarı (Dinar İmam Hatip Lisesi, 1995 Dinar depremi) (ODTÜ, 1995) (b) Kalkan duvarı hasarı (2011 Van depremi) (Alıcıuğlu, 2012)

\subsection{Rijit kat döşemesi ve duvar rijitliği}

Yığma yapılarda "rijit" bir kat döşemesi varsa, yatay yükler, düşey duvar parçalarına, rijitlikleri ile orantılı olarak dağılır. Burada "rijit" döşeme, bilindiği üzere, yatay yük altında kendi düzleminde şekil değiştirmeyen ve duvarları üst başlarından birbirine sıkıca bağlamış döşemedir. Duvar rijitliği de, duvar parçası boyunun duvar yüksekliğine oranına bağlıdır. Bütün duvarların aynı kalınlıkta olması ve rijit döşeme bulunması durumunda yatay yükler duvarlara daha da orantılı olarak dağglır (Bayülke, 2011).

Yığma yapılarda depremde gelen yatay yükler altında iki tip davranış gözlenmektedir. Kat düzeyinde betonarme döşemesi olan yapılarda bu "rijit" döşeme, deprem yüklerini duvarlara rijitlikleri ile orantılı olarak dağıtmakta ve duvarlarda "kesme" kırılmaları olmaktadır. Rijit kat döşemesi olmayan ahşap döşeme ya da çatı makası ile bağlanmış yığma yapılarda ise duvarlar zemine ankastre kirişler gibi davranıp düzlemlerine dik yönde salınım yapmakta ve yapı köşelerinde ayrışmalar biçiminde hasar başlangıcı görülmektedir. Özellikle geniş hacimli ve yüksek duvarlı ya da kat seviyeli yapılarda hasar köşelerde ayrışma biçiminde olmaktadır. Ayrıca çatı kirişlerinin duvara oturdukları yerlerin kısa olması yanında ahşabın zamanla çürümesi ya da organik zararlılarca bozulması ile çatı-duvar bağlantısı zayıflamaktadır. Bu iki farklı hasar biçimi, Şekil 2. 18a ve b' de, 1970 Gediz depreminde aynı köyde gözlenmiş birbirine çok yakın iki yığma yapının hasar görüntüsünden anlaş1labilir. Rijit kat döşemeli ve ve çok miktarda duvar boşluğu olan yapıda, boşluklar arasındaki dolu duvarda kesme kırılması oluşmuştur (Bayülke, 2011). Rijit kat döşemesi, yığma yapı davranışına olumlu katkı sağlarken, bununla orantılı olarak kesme dayanımı güçlü olacak şekilde boyutlama ve yapı malzemesi ile tekniği seçilmez, mimari sakıncalı durumlara dikkat edilmezse, olumsuz bir hal de oluşturabilir. Zira rijitliği sağladıkları için, duvar yüksekliği tabandaki duvar kalınlığının 8 katını geçmeyen yapıların deprem davranışlarının iyi olduğu gözlemlenmiştir (Arun, 2005). 


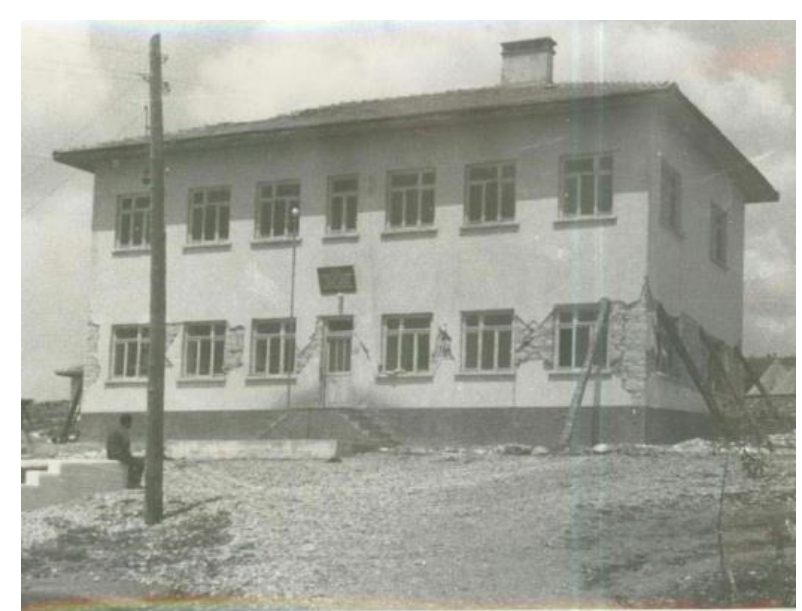

Şekil 2.18. (a) Rijit Kat Döşemeli Yığma Yapıda Deprem Hasarı (b) Esnek kat döşemeli Yığma Yapıda Deprem Hasarı (1970 Gediz depremi) (Bayülke, 2011)

\subsection{Duvar oranı}

Yapının belli bir yöndeki duvarlarnın toplam boyunun yapının plan alanına bölünmesi ile hesaplanan bir orandır. DBYBHY-2007'de bu oranın 0.25 'den daha büyük olması istenir ki geçmiş bazı depremlerde gözlenmiş yığma yapı davranışı bu kuralı desteklemektedir (Bayülke, 1977)

\subsection{Destek duvarları}

Bu madde, duvar "kararlılığı" olarak da tanımlanır. Söz konusu kararlılık, bir yönde uzanan duvara dik yönde bağlanmış duvarlar arasındaki uzunluğa bağlıdır. DBYBHY-2007'ye göre bu aralık birinci derece deprem bölgesinde 5.50 metre, diğer bölgelerde 7.0 metre olarak tanımlanmıştır. Aralarına 4.00 metrede bir betonarme kolon konulması ile duvar karalılı̆̆ 16.00 metreye kadar çıkarılabilir. Bu sayede deprem yükleri duvarlara rijitlikleri oranında dağıtılacaktır ve "uzun" duvarların düzlemleri dışına devrilmeleri önlenecektir (Bayülke, 2011). Ayrıca, desteklenmemiş duvar uzunluğu, duvar kalınlığının 10 katını geçmeyen duvarların depremlerde iyi davrandığı gözlemlenmiştir. (Arun, 2005)

\subsection{Konsol çıkma}

Özellikle Türkiye'nin Batı bölgelerinde kırsal yapılarda, ahşap destekli kerpiç yığma yapı sistemlerinde konsol çıkmalar yapıla gelmektedir. Bunlar büyük hasarlara neden olduğundan tüm yığma yapı türlerinde kesinlikle kaçınılması gerekmektedir (Şekil 2. 19) (Çelebi, Saatçığlu, 2002).
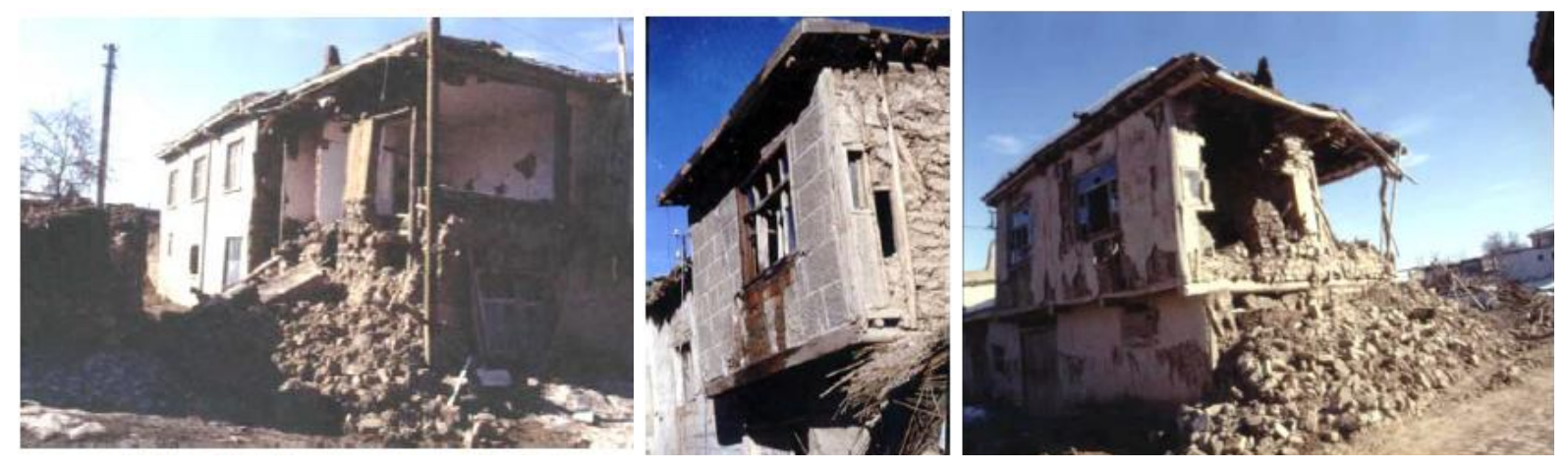
Şekil 2.19. Tamamen yıkılan ya da hasar gören konsol cephe örnekleri (Afyon-Sultandağ1 depremi) (Çelebi, Saatçığlu, 2002).

\section{Sonuçlar:}

Bu çalışmada Türkiye'de gerçekleşmiş 9 depremin yığma ve kırsal yapılar üzerindeki etkileri incelenerek aşağıda sıralanan ve literatürde yer yer bulunan, yığma yapı yapımında dikkate alınması gereken kurallar bir arada çıkarılmış ve makale metninde bu kuraların eksikliği sonucu oluşan hasarlar derlenerek fiziksel yorumları yapılmaya çalışılmıştır. Söz konusu kurallar şu şekilde verilebilir:

1-) Ağır Çatıdan Kaçınılmalıdır 2-) Duvar Altı Hatılları Yapılmalıdır 3-) Duvarın Düzlem Dışı Zorlanması Sınırlandırılmalı ve Duvar Üstü Hatılları Yapılmalıdır 4-) Duvarlardaki Çekme- Kesme Zorlanmaları karşılanmalıdır 5-) Sağlam ve Rijit Köşe Bağlantısı Yapılmalıdır 6-) Cephe Boşlukları ve Yarı- Yığma- Karkas Taşıyıcı Sistem Etkisi Dikkate Alınmalıdır 7-) Duvar ve Harç Malzemesinin Etkisi ile Düşey- Yatay Ara Hatıl Kullanımının Önemi Bilinmelidir 8-) Olası Temel Oturmalarına Dikkat Edilmelidir 9-) Çok Boşluklu Tuğa Kullanımından Kaçınılmalıdır 10-) Kalkan Duvarı Hasarları Yatay Düşey Hatıllarla Önlenmelidir 11-) Rijit Kat Döşemesinin ve Duvar Rijitliğinin Önemine Dikkat Edilmelidir 12-)Duvar Oranına Bakılmalıdır 13-) Destek Duvarları Kullanılmalıdır 14-) Konsol Çıkmadan Kaçınılmalıdır

Teşekkür: $\mathrm{Bu}$ makalenin hazırlanmasında araştırmalarıyla yardımda bulunan inşaat mühendisi Azize Karahan'a teşekkürlerimi sunarım.

\section{Kaynakça}

Alıcıoğlu M.B.,2012,Van İli Hasar Tespiti ve Depremin Yapılar Üstündeki Etkisi, 13.05.2016, http://www.csb.gov.tr/iller/manisa/index.php?Sayfa=etkinlikdetay\&Id=505

Alkaya D., 2005, Sultandağı Depremi Işı̆̆ında Toprak Yapılar ve İyileştirme Önerileri, YDGA2005 - Yığma Yapıların Deprem Güvenliğinin Arttırılması Çalıştayı, 17 Şubat, Orta Doğu Teknik Üniversitesi, Ankara,108-123.

Arun G., 2005, Yığma Kagir Yapı Davranışı, YDGA 2005 - Yığma Yapıların Deprem Güvenliğinin Arttırılması Çalıştayı, 17 Şubat, Orta Doğu Teknik Üniversitesi, Ankara, 76-89.

Batur N. ve Kaplan S. A., 2006, Yı̆̆ma Yapı Tasarım ve Analizi, İ.Ü. Müh. Fak. İnş. Böl., Bitirme tezi, 13-15.

Bayraktar, A., Coşkun, N., Yalçın, A., 2007, Damages of Masonry Buildings During the July 2, 2004 Doğubayazıt (Ağrı) Earthquake in Turkey, Engineering Failure Analysis, 14, $147-157$.

Bayülke, N., 1977, 24 Kasım 1976 Çaldıran-Muradiye ve 25 Mart 1977 Palu Depremlerinde Hasar Gören Bazı Yığma Yapılar Üzerinde İnceleme, İmar ve İskan Bakanlığı Deprem Araştırma Enstitüsü Başkanlığı, Ankara, 22- 28

Bayülke, N., 1980, Yığma Yapılar, T.C. İmar ve İskan Bakanlığı Deprem Araştırma Enstitüsü 
Başkanlığı, Ankara, 21-46.

Bayülke, N.,1990, Kerpiç Yapı Sarsma Tablası Deney Raporu, Bayındırlık ve İskan Bakanlığı, Deprem Araştırma Dairesi Başkanlığı, Ankara, 12-26.

Bayülke, N. ,1992, Yığma Yapılar (Genişletilmiş 2nci Baskı), Bayındırlık ve İskan Bakanlığ1 Deprem Araştırma Dairesi Başkanlığı, Ankara, 26-28.

Bayülke, N., 2003, Betonarme Yapının Dolgu Duvarı, TMH- Türkiye Mühendislik Haberleri, Say1 426 (4), 85-98.

Bayülke, N., 2011, Yığma Yapıların Deprem Davranışı ve Güvenliği, 1. Türkiye Deprem Mühendisliği ve Sismoloji Konferans1, 11- 14 Ekim, ODTÜ, Ankara, 23-36.

Binici, H., Durgun, M. Y., Yardım, Y., 2010, Kerpiç Yapılar Depreme Dayanıksız mıdır? Avantajları ve dezavantajları nedir?, KSÜ Müh. Bil. Dergisi, 13(2), 1-10.

Celep, Z., Kumbasar, N., 2004, Deprem Mühendisliğine Giriş ve Depreme Dayanıklı Yap1 Tasarımı, İstanbul, 33-35.

Çelebi R. ve Saatcıoğlu N.Ö., 2002, Afyon Depremi ve Düşündürdükleri, Uludağ Ünv. Müh. Mim. Fak. Dergisi, Cilt 7, Sayı 1, 15- 28.

Çırak, İ. F., 2011, Yı̆̆ma Yapılarda Oluşan Hasarlar, Nedenleri ve Öneriler, SDU International Technologic Science, Vol.3, No 2, 55-60.

Doğangün, A., Ural, A., Livaoğlu, R., 2008, Seismic Performance of Masonry Buildings During Recent Earthquakes In Turkey, The 14th World Conference on Earthquake Engineering October 12-17, Beijing, China,

Gölalmış, M., A. Türer, A., 2005, Kullanılmış Araba Lastikleri Kullanarak Yığma Bina Duvarlarının Depreme Karşı Güçlendirme Çalışmaları YDGA2005 - Yığma Yapıların Deprem Güvenliğinin Arttırılması Çalıştayı, 17 Şubat, Orta Doğu Teknik Üniversitesi, Ankara, 35- 48.

Gürdil, F., 1984, Kerpiç Blokların Fiziki ve Mekanik Özelliklerinin İyileştirilmesi. 1 nci Kuzeydoğu Anadolu Ulusal Deprem Sempozyumu, 16-19 Mayıs, Erzurum, Bildiriler Kitab1, 152-164.

İTÜ Yapı ve Deprem Uygulama- Araştırma Merkezi, 1992, 13 Mart 1992 Erzincan Depremi hakkında Rapor I, İstanbul, 11-16.

Karaşin A. ve Karaesmen E., 2005,1 Mayıs Bingöl Depreminde Meydana Gelen Yığma Yapı Hasarları, YDGA2005 - Yığma Yapıların Deprem Güvenliğinin Arttırılması Çalıştayı, 17 Şubat, Orta Doğu Teknik Üniversitesi, Ankara, 90-107.

Kanıt R., Erdal M., Işık N.S., Can Ö., Yener M.K., Serimer G., Uğur L.O., Atımtay E., 2005, Düzlem Dışı Yüklenen Yığma Yapıların Deneysel Davranışı, YDGA2005 - Yığma Yapıların Deprem Güvenliğinin Arttırılması Çalıştayı, 17 Şubat, Orta Doğu Teknik Üniversitesi, Ankara, 136-144. 
Koçu N., Korkmaz Z., 2004, Kerpiç Malzeme ile Üretilen Yapılarda Deprem Etkilerinin Tespiti, TMMOB. Mimarlar Odası İstanbul Büyükkent Şubesi, 2. Ulusal Yap1 Malzemesi Kongresi, 6-8 Ekim, İstanbul, 52-62.

Korkmaz S., Z., Korkmaz, H., H., Türer A., 2005, Elastik Art- Germe Şeritleriyle, Yığma Yapıların Güçlendirilmesi, YDGA 2005 - Yığma Yapıların Deprem Güvenliğinin Arttırılması Çalıştayı, 17 Şubat, Orta Doğu Teknik Üniversitesi, Ankara, 64- 75.

Kumbasar H., Aydan Ö., Tano H., Çelik S. B., Kaya M., 2006, Temmuz 2003 Buldan (Denizli) Depremlerinin Mühendislik İncelemesi, Buldan Sempozyumu, 23-24 Kasım, Pamukkale Ünv. Denizli, 93- 110.

ODTÜ İnş. Müh. Böl. Deprem Araştırma Merkezi, 1995, 1 Ekim 1995 Dinar Depremi Mühendislik Raporu, TMMOB İnşaat Mühendisleri Odası Ankara Şubesi, Ankara, 112.

Pamukkale Üniversitesi Mühendislik Fakültesi, İnşaat Mühendisliği Bölümü, 2003, 23 - 26 Temmuz 2003 Buldan/Denizli Depremi Mühendislik Raporu, Denizli, 4-14.

Pınar, M., 2004, Çağlar Boyunca Gediz, Eskigediz Belediyesi Kültür Yayınları 1, 55.

Sevmiş M., Mart 2005, 25 Ocak 2005 Hakkari Depremi Ön Raporu, Teknik Güç Dergisi, 3

Şimşek Ç., 2005, Kırsaldaki Yığma Yapılar ve Deprem Güvenliklerinin Sağlanmasındaki Sosyal ve Kurumsal Etmenler, YDGA2005 - Yığma Yapıların Deprem Güvenliğinin Arttırılması Çalıştayı, 17 Şubat, Orta Doğu Teknik Üniversitesi, Ankara, 49-63.

TC. Başbakanlık Devlet İstatistik Enstitüsü, 2001, Bina Sayımı 2000, DİE Matbaas1, Ankara, 236-238.

Tokgöz H., Can Ö., 2011, Dıştan Perde Duvarla Güçlendirmede Perde- Hatıl Birleşim Yerlerine Kullanılan Blon Sayısının Araştırılması, Gazi Üniversitesi Müh. Mim. Fak. Der., Cilt 26, No.3, 649-656. 